\title{
Macrophages Counteract Demyelination in a Mouse Model of Globoid Cell Leukodystrophy
}

\author{
Yoichi Kondo, ${ }^{1}$ Jessica M. Adams, ${ }^{1}$ Marie T. Vanier, ${ }^{2}$ and Ian D. Duncan ${ }^{1}$ \\ ${ }^{1}$ Department of Medical Sciences, School of Veterinary Medicine, University of Wisconsin-Madison, Madison, Wisconsin 53706, and ${ }^{2}$ Institut de la Santé et \\ de la Recherche Médicale Unit 820 and Lyon 1 University, Lyon, France
}

Whether microglia and macrophages are beneficial or harmful in many neurological disorders, including demyelinating diseases such as multiple sclerosis and the leukodystrophies, is currently under debate. Answering this question is of special interest in globoid cell leukodystrophy (GLD), a genetic fatal demyelinating disease, because its rapidly progressive demyelination in the nervous system is accompanied by a characteristic accumulation of numerous globoid macrophages. Therefore, we cross-bred the twitcher ( $t w i)$ mouse, a bona fide model of GLD, with the macrophage-deficient osteopetrotic mutant and studied the resultant macrophage-deficient twitcher $(t w i+o p)$ mouse. The $t w i+o p$ mouse had few microglia and macrophages in the white matter and, interestingly, showed a more severe clinical phenotype compared to the $t w i$ mouse. The number of nonmyelinated axons in the spinal cord was significantly higher in $t w i+o p$ mice than in twi mice at $45 \mathrm{~d}$ old. The difference appeared to be due to impaired remyelination in $t w i+o p$ mice rather than accelerated demyelination. Quantitative reverse transcription PCR and immunohistochemical studies revealed that the recruitment of oligodendrocyte progenitor cells in response to demyelination was compromised in $t w i+o p$ mice. Increased myelin debris in the white matter parenchyma of twi+op mice suggested that phagocytosis by macrophages may play an important role in promoting remyelination. Macrophage markers for both protective and destructive phenotypes were significantly upregulated in the spinal cord of $t w i$ mice but were close to normal in $t w i+o p$ mice due to the reduced macrophage number. The overall effects of macrophages in GLD appear to be beneficial to myelin by promoting myelin repair.

\section{Introduction}

Microglia and macrophages are functionally divergent and the answer to whether they are beneficial or harmful may differ in many neurological disorders, including demyelinating diseases such as multiple sclerosis and the leukodystrophies (Schwartz et al., 2006; Neumann et al., 2008; Popovich and Longbrake, 2008). In addition to clearing tissue debris as phagocytes, these cells primarily appear to function as the immunocompetent cells of the CNS, initiating inflammation by secreting proinflammatory cytokines such as tumor necrosis factor (TNF)- $\alpha$, interleukin (IL) $-1 \beta$, and IL- 6 and by releasing free radicals such as nitric oxide (NO) (Hanisch and Kettenmann, 2007; Tambuyzer et al., 2009). Expression of the class II major histocompatibility complex (MHC II) on microglia/macrophages has indicated that these cells function as antigen-presenting cells that initiate $\mathrm{T}$ lymphocyte-mediated immune response (Ulvestad et al., 1994). These activities of microglia/macrophages were initially thought to be harmful to other cells of the CNS [e.g., neurons and oligodendrocytes (OLs)]. However, increasing evidence suggests that

Received Dec. 6, 2010; revised Jan. 5, 2011; accepted Jan. 17, 2011.

This work was supported by National Institutes of Health Grant R01 NS055816, the Myelin Project, and the Hunter's Hope Foundation. We thank Dr. Z. Fabry for critically reviewing the manuscript, C. Fahrenholtz, J. Ramaker, S. Martin, and S. Bowman for technical assistance, and T. Lin for statistical advice.

Correspondence should be addressed to Yoichi Kondo or lan D. Duncan, Department of Medical Sciences, School of Veterinary Medicine, University of Wisconsin-Madison, 2015 Linden Drive, Madison, WI 53706, E-mail: kondoy@svm.vetmed.wisc.edu or duncani@svm.vetmed.wisc.edu.

DOI:10.1523/JNEUROSCI.6344-10.2011

Copyright $\odot 2011$ the authors $\quad 0270-6474 / 11 / 313610-15 \$ 15.00 / 0$ microglia/macrophages may protect or promote the development and survival of neurons and OLs. For example, microgliaderived molecules such as TNF- $\alpha$ (Arnett et al., 2001), IL-1 $\beta$ (Mason et al., 2001), and MHC II (Arnett et al., 2003) have been shown to promote remyelination in mouse models of demyelination by promoting proliferation or differentiation of oligodendrocyte progenitor cells (OPCs) directly or indirectly. NO has been shown to be protective against apoptotic death of OLs (Arnett et al., 2002). Moreover, depletion of macrophages delays CNS remyelination, perhaps via induction of insulin-like growth factor (IGF)- 1 and transforming growth factor (TGF)- $\beta 1$ expression in a rat model of chemically induced demyelination (Kotter et al., 2005).

In globoid cell leukodystrophy (GLD; Krabbe's disease), the roles of microglia and macrophages in particular remain unclear. GLD is a rapidly progressive demyelinating disease caused by a genetic deficiency in the activity of a lysosomal enzyme, galactocerebrosidase (GALC) (Suzuki and Suzuki, 1970). It is pathologically characterized by the accumulation of numerous bloodborne macrophages in the CNS and PNS before or concomitant with demyelination (Taniike and Suzuki, 1994; Wenger et al., 2001). GALC defective OLs and Schwann cells are unable to degrade its substrate, galactocerebroside. Unlike other lysosomal storage diseases, however, storage of galactocerebroside in the myelinating cells does not occur while psychosine, a cytotoxic lipid metabolite, accumulates and kills OLs and Schwann cells, leading to demyelination (the psychosine hypothesis) (Miyatake and Suzuki, 1972). 
To investigate whether microglia/macrophages contribute in a positive or negative way to the pathophysiology of GLD, we cross-bred the twitcher ( $t w i)$ mouse, a bona fide model of Krabbe's disease, with the macrophage-deficient osteopetrotic ( $o p$ ) mouse (Wiktor-Jedrzejczak et al., 1990; Yoshida et al., 1990); the resultant macrophage-deficient twitcher $(t w i+o p)$ mouse was examined for the following: (1) clinical phenotypes and demyelinating pathology; (2) levels of psychosine accumulation; (3) mRNA expression levels of inflammatory molecules and growth factors; and (4) changes in phenotypic markers of macrophages.

\section{Materials and Methods}

All experimental procedures were approved by the Animal Care and Use Committee. The University of Wisconsin-Madison operates in full compliance with federal guidelines.

Generation of twi+ op double mutant. Homozygous op mice are deficient in the expression of macrophage colony-stimulating factor (CSF)-1 because of a point mutation in the CSF-1 gene that results in truncated and inactive CSF-1 protein (Wiktor-Jedrzejczak et al., 1990; Yoshida et al., 1990). To elucidate the roles of microglia/macrophages in GLD, we have created the macrophage-deficient $t w i$ mouse by cross-breeding $O P$ mice with twi mice. Heterozygous B6.CE $G A L C^{\text {twi/+ }}$ mice (The Jackson Laboratory) were bred to heterozygous $\mathrm{B} 6 \mathrm{C} 3 \mathrm{Fe} C S F-1^{\mathrm{op} /+}$ mice (The Jackson Laboratory.). F1 mice heterozygous for both $t w i$ and $o p$ mutations were identified and mated to produce the twi+op double mutant as well as the double carriers for further breeding. In this study, we analyzed the animals of F4-F11 generations. Hereafter, the animals used in this study are on this new background unless noted.

The $o p$ and $t w i+o p$ mutants were weaned at postnatal day (P)-16 and fed with liquid diet (L10012G, Research Diets) in a $35 \mathrm{~mm}$ plastic dish lid (Corning) twice a day. They also had ad libitum access to powdered rodent diet (Harlan Teklad). To ease the difficulty in eating and drinking in later life, we also fed twi mice with the liquid diet after weaning at P21 as well as crushed food pellets on the cage floor. The animals were immediately killed when they became paraplegic or were unable to take food or water.

PCR diagnosis of GALC and CSF-1 genotypes. To identify twi and op mutation, we combined two previously reported methods for PCR of genomic DNA- one for twi mutation (Sakai et al., 1996) and the other for $o p$ mutation (Lieschke et al., 1994). The primers were as follows: twi sense primer (5'-CACTTAATTTTCTCCAGTCAT-3') and antisense primer (5'TAGATGGCCCACTGTCTTCAGGTGATA-3'); op sense primer ( $5^{\prime}$-TGTGTCCCTTCCTCAGATTACA-3') and antisense primer (5'-GGTCTCATCTATTATGTCTTGTACCAGCCAAAA-3'). The underlined CC indicates a mismatch sequence. The PCR mixture $(20 \mu \mathrm{l})$ contained $2.5 \mathrm{mM} \mathrm{MgCl}_{2}, 125 \mu \mathrm{m}$ each dNTP, $100 \mathrm{~nm}$ each primer, $10 \times$ PCR buffer (Promega), $0.025 \mathrm{U} / \mu \mathrm{l} \mathrm{TaqDNA}$ polymerase (Promega), and $2 \mu \mathrm{l}$ of genomic DNA isolated from tail tip biopsy. The samples were denatured for $2 \mathrm{~min}$ at $94^{\circ} \mathrm{C}$, followed by 35 cycles of $94^{\circ} \mathrm{C}$ for $30 \mathrm{~s}, 50^{\circ} \mathrm{C}$ for $30 \mathrm{~s}$, and $72^{\circ} \mathrm{C}$ for $30 \mathrm{~s}$, and the final extension reaction at $72^{\circ} \mathrm{C}$ for 7 min. The PCR products were digested with $5 \mathrm{U}$ of EcoRV and $5 \mathrm{U}$ of BglI in buffer D (Promega) per $20 \mu \mathrm{l}$ of PCR product for $1 \mathrm{~h}$ at $37^{\circ} \mathrm{C}$. The digested fragments were separated by $8 \%$ polyacrylamide gel and visualized by ethidium bromide. This analysis demonstrated following fragments: for the twi mutation, $260 \mathrm{bp}$ for wild type, $240 \mathrm{bp}$ for $G A L C^{t w i / t w i}$, and both for $G A L C^{t w i /+}$; for the op mutation, 96 bp constant band plus $99 \mathrm{bp}$ for wild type, $70 \mathrm{bp}$ for CSF-1 $1^{o p / o p}$, and both for CSF-1 $1^{o p /+}$.

Histology. To avoid potentially large variations or misleading of results based on sex differences in parameters of OLs and myelin (Mack et al., 1995; Cerghet et al., 2006; Li et al., 2006; Kim and Juraska, 1997), we used only female mice for the histological analyses and male mice for the biochemical, Western blot, and gene expression analyses. Methods for immunohistochemistry, toluidine blue myelin staining, and electron microscopy have been described previously in detail (Kondo et al., 2005). Briefly, female wild-type, $o p$, twi, and twi+op mice at P15, P30, P40, and $\mathrm{P} 45$ ( $n=3$ each group) were injected with 5-bromo-2'-deoxyuridine (100 mg/kg in saline, i.p.; Sigma) 8, 16, and $24 \mathrm{~h}$ before killing and perfusion fixed with $4 \%$ paraformaldehyde and $0.2 \%$ picric acid in $0.1 \mathrm{M}$ phosphate buffer (PB), pH 7.4. The brain, spinal cord, and sciatic nerves were removed and postfixed for a further $10 \mathrm{~h}$. Free-floating sections were cut on a cryostat at $20 \mu \mathrm{m}$ for immunohistochemistry. The freefloating sections were immunolabeled with the following primary antibodies: rabbit anti-glial fibrillary acidic protein (GFAP) (DakoCytomation, 1:80,000); rabbit anti-NG2 chondroitin sulfate proteoglycan (Millipore, 1:5000); rabbit anti- $\pi$ form of glutathione $S$-transferase (GST- $\pi$ ) (MBL, 1:100,000); rabbit anti-Iba-1 antibody (Wako, 1:5000); and rat anti-mouse CD45 (Serotec, clone IBL-3/16, 1:5000). We used the anti-CD45 antibody to demonstrate microglia/macrophages at lower magnifications (see Fig. 2A), as it gave the crispest staining among the monocyte markers tested. Although CD45 is a pan-leukocyte marker, we took advantage of the unique pathology of GLD that is devoid of leukocytes other than macrophages (Ohno et al., 1993; Matsushima et al., 1994). For negative control staining, the primary antibodies were omitted and no staining was observed. Iba-1(1:500) immunolabeling for the sciatic nerve (see Fig. 5) was performed on slide-mounted sections cut at $6 \mu \mathrm{m}$.

For the double-immunofluorescence staining shown in Figures 8 and 9 , lighter fixation was used to obtain optimal staining with fixationsensitive antibodies. Briefly, the animals ( $n=4$ each group) were perfusion-fixed with $20 \mathrm{ml}$ of $4 \%$ paraformaldehyde in $\mathrm{PB}$ followed by 20 $\mathrm{ml}$ of $7.5 \%$ sucrose in PB and $20 \mathrm{ml}$ of $15 \%$ sucrose in PB. The cervical spinal cord was removed, immediately snap-frozen with dry ice powder, cut at $10 \mu \mathrm{m}$ on the cryostat, mounted on glass slides, and kept at $-80^{\circ} \mathrm{C}$ until use. Sections were incubated with 5\% normal donkey serum (NDS) in $\mathrm{PB}$ containing $0.3 \%$ Triton $\mathrm{X}-100$ for $15 \mathrm{~min}$ and then with the first primary antibody overnight at $4{ }^{\circ} \mathrm{C}$, followed by the second primary antibody, rabbit anti-Iba-1 (1:500), for $1 \mathrm{~h}$ at room temperature. The first primary antibodies were as follows: rabbit anti-arginase-1 (Santa Cruz Biotechnology, H-52, 1:100); rat anti-CD206 (Serotec, clone 5D3, 1:50); rat anti-mouse CD16/CD32 (BD Biosciences, clone 2.4G2, 1:800); hamster anti-mouse CD11c (eBioscience, clone N418, 1:50); and rat anti-mouse CD11b (Serotec, M1/70.15, 1:500). These antigens were visualized by Alexa Fluor 488- or 594-conjugated secondary antibodies of an appropriate host species (Invitrogen; 1:100). The above antibodies were diluted in 5\% NDS/10 mм PBS, pH 7.2. Omitting primary antibodies yielded no significant staining.

Periodic acid Schiff (PAS) staining was performed on $4 \mu \mathrm{m}$ paraffinembedded sections. Cervical spinal cord segments (C3-C4) and midsciatic nerves were further fixed in $2.5 \%$ glutaraldehyde in $\mathrm{PB}$, embedded in epon plastic, and used for toluidine blue myelin staining and electron microscopy.

Morphometric analyses for myelination. To compare the demyelinating pathology of twi and twi+op mice, we analyzed the number of myelinated axons and the thickness of myelin on the toluidine blue-stained sections from the cervical spinal cord of wild-type, $o p$, twi, and twi+op mice at $45 \mathrm{~d}$ old ( $n=3$ each group). Four rectangular areas $\left(2489 \mu \mathrm{m}^{2}\right.$ each) bilaterally adjacent to the ventral fissure of the spinal ventral column were recorded with the SPOT CCD camera (Diagnostic Instruments) through a $100 \times$ objective lens plus $2 \times$ projection lens on the Nikon Eclipse E800M light microscope. The numbers of nonmyelinated and myelinated axons and the axons that had degenerating myelin were counted in the two rectangles per animal in a blinded manner. Degenerating myelin was defined as that which was detached from the axon perimeter and/or whose lamellae were split. Even in the wild-type control, some axons had myelin categorized as "degenerating", which was a potential artifact. However, the numbers appeared to be negligible (see Fig. 3B).

The G-ratios (axon diameter/total fiber diameter) were determined using the MetaVue software (Molecular Devices). Only the myelinated axons in contact with two diagonal lines drawn on each rectangle were analyzed (283-492 axons per group of three animals). When the axons were not exactly circular, the shortest diameter was measured.

Area measurement for PAS-positive material. The ventral white matter of the cervical spinal cord stained with PAS was photographed bilaterally with the SPOT CCD camera through a $20 \times$ objective lens on the light microscope. PAS-positive areas in these images were traced using the ImageJ software (version 1.42, National Institutes of Health), and the total PAS-positive pixel area was expressed as percentage area over 
the total pixel area of the photograph. Each value was an average of percentage area from the right and left ventral column ( $n=3$ per group).

Morphometric analyses for immunohistochemistry. The following quantitative studies were performed on the ventral white matter of the cervical spinal cord at $45 \mathrm{~d}$ of age. We quantitated microglia/macrophages histologically by measuring the Iba-1- or CD11b-immunoreactive area rather than by counting the number of immunoreactive cells because of the potential inaccuracy in counting macrophages that are often clustered, fused, and/or multinucleated in twi mice.

For GFAP immunoreactivity, the exposure time was optimized for the wild-type control section and applied to all the photographs to record unbiased optical densities (ODs). Using the ImageJ software, the ventral white matter was manually traced and ODs were inverted so that black and white are defined as 255 and 0 , respectively. The average OD per pixel in the selected white matter was calculated. Six measurements (bilateral measurements from three sections) were averaged for one animal, and the average from three animals was obtained for each genotype.

$\mathrm{NG} 2{ }^{+}$OPCs and GST- $\pi^{+}$OLs were counted on sections lightly counterstained with hematoxylin. Only the immunoreactive cells that had a nucleus were counted. $\mathrm{NG}^{+}{ }^{+}$macrophages, defined morphologically as cells with round cytoplasm without processes, were excluded.

Areas of macrophages as shown in Figures 8 and 9 were measured on the immunofluorescence-labeled spinal cord sections ( $n=4$ per group; values from four sections were averaged per animal). The exposure time was set for the optimal condition for twi mouse sections, which showed the most intense signals. A constant threshold was set on the digitally recorded images so that it detected all microglia in wild-type mice. The areas that had signal intensities above the threshold were determined within manually traced ventral white matter using the NIH Image software.

To analyze myelination in the sciatic nerve as shown in Figure 5, crosssections of the mid-sciatic nerve $(6 \mu \mathrm{m})$ were immunolabeled for myelin basic protein (MBP) using rat anti-MBP antibody (Millipore, peptides 82-87, 1:100) and Alexa Fluor 594-conjugated anti-rat IgG (Invitrogen, $1: 100)$. On the ImageJ software, a constant threshold was set so that it detected all MBP-immunoreactive areas in $t w i+o p$ mice and the $\mathrm{MBP}^{+}$ signals were recorded within the manually traced nerve circumference. Data were obtained from three animals per group, and the data for each animal were the average of the values from four sections examined. A volume effect was a potential concern for unbiased quantitation, because the sciatic nerves were markedly hypertrophic in $t w i$ and $t w i+o p$ mice. Therefore, the data were presented in two ways, i.e., the percentage $\mathrm{MBP}^{+}$area (Fig. 5C) and $\mathrm{MBP}^{+}$pixels per section (Fig. 5D).

Biochemical assay. The levels of psychosine and sphingosine were determined in the forebrain of 45 -d-old male mice ( $n=3$ each group) using high performance liquid chromatography (HPLC) as described previously (Luzi et al., 2001). After euthanizing the animals with isoflurane over-inhalation, the right and left forebrains were removed, frozen immediately in dry ice, and kept at $-80^{\circ} \mathrm{C}$ until the assay. Values for each animal were an average of measurements from the right and left brain hemispheres.

Quantitative real-time reverse transcription PCR. The cervical spinal cord from the male mice at P45 (the same animals as in the biochemical assay) was removed, transferred into a $1.5 \mathrm{ml}$ centrifuge tube containing RNA lysis buffer (Promega, homogenized with a plastic pestle until recognizable tissue fragments disappeared, and kept at $-80^{\circ} \mathrm{C}$. After all the necessary samples were collected, they were thawed on ice and total RNA was isolated using SV Total RNA Isolation System (Promega) according to the instructions. The yield of total RNA was $18.2 \pm 1.7 \mu \mathrm{g}$ from $32.9 \pm$ $1.6 \mathrm{mg}$ (wet weight) of the cervical spinal cord $(n=12)$. The quality of isolated RNA was confirmed by electrophoresis on a denaturing agarose gel, which showed sharp $28 \mathrm{~S}$ and $18 \mathrm{~S}$ ribosomal RNA bands and $\sim 2: 1$ ratio of their intensity after ethidium bromide staining. RNA was then reverse transcribed to cDNA using oligo $(\mathrm{dT})_{15}$ primer and the ImProm-II Reverse Transcription System (Promega).

cDNAs corresponding to 5 ng of total RNA were amplified with specific primers designed to span intronic sequences or cover exon-intron boundaries using the online version of Primer3 software (Rozen and Skaletsky, 2000) (Table 1 for primer sequences), except that the primers
Table 1. Primer sequences for real-time RT-PCR analysis

\begin{tabular}{|c|c|c|c|}
\hline$\overline{\text { Gene }}$ & Forward primer $\left(5^{\prime}-3^{\prime}\right)$ & Reverse primer $\left(5^{\prime}-3^{\prime}\right)$ & Amplicon (bp) \\
\hline $\operatorname{CD} 3 \gamma$ & САAACCCCCTGCAAGTGTAT & GAAGCTCTTGACTGGCGAAC & 163 \\
\hline CD4 & AGGAAGTGAACCTGGTGGTG & TCCTGGAGTCCATCTTGACC & 222 \\
\hline CD8b & GGACGAAGCTGACTGTGGTT & CAGGATGCAGACTACCAGCA & 164 \\
\hline CD11b & CTGAGACTGGAGGCAACCAT & GATATCTCCTTCGCGCAGAC & 159 \\
\hline CD11C & GAGAGCCCAGACGAAGACAG & ССАTTTGCTTCСТССААСАT & 171 \\
\hline CD16 & TGTTTGCTTTTGCAGACAGG & CGTGTAGCTGGATTGGACCT & 194 \\
\hline CD28 & TGACACTCAGGCTGCTGTTC & TTCCTTTGCGAGAAGGTTGT & 152 \\
\hline CD80 & CCATGTCCAAGGCTCATTCT & GGCAAGGCAGCAATACCTTA & 115 \\
\hline CD86 & TCAGTGATCGCCAACTTCAG & TTAGGTTTCGGGTGACCTTG & 110 \\
\hline CD206 & CCTCTGGTGAACGGAATGAT & CTTCCTTTGGTCAGCTTTGG & 161 \\
\hline $\mathrm{FoxP}^{a}$ & TCCTTCCCAGAGTTCTTCCA & AAGTAGGCGAACATGCGAGT & 164 \\
\hline GFAP & GTTACCAGGAGGCACTTGCT & GAATGGTGATGCGGTTTTCT & 171 \\
\hline IGF-1 & TGGATGCTCTTCAGTTCGTG & GTCTTGGGCATGTCAGTGTG & 220 \\
\hline $\mathrm{IL}-1 \beta$ & TGTGAAATGCCACCTTTTGA & CTGCCTGAAGCTCTTGTTGA & 162 \\
\hline IL-6 & TGTGCAATGGCAATTCTGAT & CTCTGAAGGACTCTGGCTTTG & 226 \\
\hline LIF & TTCATTTCCTATTACACAGCTCAAG & AGTGGGGTTCAGGACCTTCT & 201 \\
\hline MBP & TCACACACGAGAACTACCCATT & TGGTGTTCGAGGTGTCACAA & 138 \\
\hline MHC II & GCTCTCGGAGACCTATGACG & ACAGGCAAACCTCTGGACAC & 210 \\
\hline PDGF-R $\alpha$ & GCCGGGACAATACAAGAAGA & CACTGTCAGCGCTCAGTCTC & 188 \\
\hline PLP/DM20 & CGCTGATGCCAGAATGTATG & TGAAGGTGAGCAGGGAAACT & 170 \\
\hline PLP-sp ${ }^{b}$ & CTGAGCGCAACGGTAACAG & CAAACTTGTCGGGATGTCCT & 121 \\
\hline TGF- $\beta 1$ & TTGCTTCAGCTCCACAGAGA & TGGTTGTAGAGGGCAAGGAC & 183 \\
\hline TNF- $\alpha$ & CCACCACGCTCTTCTGTCTA & CACTTGGTGGTTTGCTACGA & 173 \\
\hline
\end{tabular}

${ }^{a}$ FoxP3, Forkhead box P3.

${ }^{b}$ PLP-sp, Primers for PLP designed to specifically detect the PLP CDNA sequence that is absent from the DM20 CDNA.

for arginase-1 were referred to the study by Kigerl et al. (2009), and the following primers were referred by the Primer Bank (http://pga.mgh.harvard. edu/primerbank/): GAPDH (glyceraldehyde-3-phosphate dehydrogenase; PrimerBank identification no. 6679937a1); iNOS (inducible nitric oxide synthase 2, macrophage, PrimerBank identification no. 6754872a1). The samples prepared with a SYBR Green master mix (SYBR Green I Master; Bio-Rad Laboratories) were run on the MiniOpticon system (Bio-Rad) for continuous monitoring during PCR amplification. Two-step PCR cycling was carried out as follows: 1 cycle at $95^{\circ} \mathrm{C}$ for $5 \mathrm{~s}$ and $60^{\circ} \mathrm{C}$ for $30 \mathrm{~s} \times$ 45 cycles. The analysis of the melting curve of each amplified PCR product and the visualization of the PCR amplicons on $8 \%$ polyacrylamide gels confirmed the specificity of the amplification. For relative quantification of gene expression, mRNA levels were normalized to the average GAPDH mRNA levels using the comparative threshold cycle $\Delta \mathrm{C}_{\mathrm{T}}$ method. Each reaction was performed in duplicate.

Western blot analysis. Protein extract was prepared from the thoracic and lumbar spinal cords of male mice at $\mathrm{P} 45$ ( $n=3$ each group) in $20 \mathrm{~mm}$ Tris $\mathrm{HCl}$ lysis buffer, $\mathrm{pH}$ 7.6, containing $150 \mathrm{~mm} \mathrm{NaCl}, 1 \%$ IGEPAL CA-630 (Sigma-Aldrich), 0.5\% sodium deoxycholate, 0.1\% SDS, and protease inhibitors (Complete, Roche). Protein concentration was determined using the Qubit fluorometer (Invitrogen), and the samples (30 $\mu \mathrm{g}$ each) were separated on the AnykD TGX precast gel (Bio-Rad) and transferred onto polyvinylidene difluoride membranes (Invitrogen). The membranes were blocked for $4 \mathrm{~h}$ in $5 \%$ bovine serum albumin in $20 \mathrm{~mm}$ Tris- $\mathrm{HCl}$ buffer containing $150 \mathrm{~mm} \mathrm{HCl}$ and $0.05 \%$ Tween 20, pH 7.6 (TBS-T), and incubated with the rabbit anti-arginase- 1 antibody (1:200) overnight at $4^{\circ} \mathrm{C}$. Membranes were washed in TBS-T and incubated with goat anti-rabbit horseradish peroxidase (HRP)-conjugated secondary antibody (1:50,000; Jackson ImmunoResearch Laboratories). The bound HRP activity was visualized by a chemiluminescent substrate (Thermo Scientific) and recorded using the Autochemi bioimaging system (UVP). The membrane was reprobed with monoclonal mouse anti- $\beta$-tubulin antibody (Sigma-Aldrich, clone AA2, 1: 2000) to ensure equal loading of samples. ODs of bands were measured using the ImageJ software. The ODs for arginase- 1 were normalized over the ODs for $\beta$-tubulin, and these values were expressed as the ratio relative to the wild-type control.

Statistical analyses. The difference in the life span of twi and twi+op mice was examine by Kaplan-Meier log-rank analysis (see Fig. $1 C$ ). The G-ratios were compared by the Kruskal-Wallis test (see Fig. $3 F$ ). The PAS-positive areas in the spinal cord of $t w i$ and $t w i+o p$ mice were com- 
pared by the paired Student's $t$ test. Other differences between groups were assessed by one-way ANOVA followed by Scheffe's F post hoc comparisons. Data are expressed as mean \pm SE unless noted. Values of $p<$ 0.05 were considered statistically significant.

\section{Results}

Macrophage-deficiency in twi mice leads to their shorter life span with exacerbated neurological symptoms

We introduced macrophage deficiency in the mouse model of GLD by crossbreeding twi onto op mice and first characterized the clinical phenotypes of the resultant twi+op double-mutant. Only $2.0 \%$ of the crossbred mice yielded the twi+op doublemutant mouse (of 1969 pups genotyped), whereas its expected Mendelian distribution is $6.25 \%$. This appears to be mainly due to the poor reproduction of op mice $(7.9 \%$ versus the expected ratio of $18.75 \%$ ), which is consistent with a previous report (Ramnaraine and Clohisy, 1998). Indeed, when the pups were born dead or found dead at P0-P1, genotyping identified seven of ten pups as op mice and two twi+op mice, indicating that a considerable number of $o p$ mutants die perinatally. However, after passing the perinatal period, all op and twi+op mutants were able to survive beyond weaning age with the aid of the liquid diet (Kondo and Duncan, 2009).

The double mutants had similar physical characteristics to op mice. They exhibited a domed scull and lack of incisors (Fig. 1A) and were smaller in size than $t w i$ and $o p$ mice (Fig. $1 B$ ). Although the growth of $o p$ mice was slower than that of wild-type mice (Fig. $1 \mathrm{~B})$, they exhibited no neurological signs and were able to live at least a year when allowed. Similarly, twi+op mice were smaller than twi and the body weight of twi+op mice started to decline between P29 and P33, whereas twi mice started losing weight after P35 (Fig. $1 B$ ). The double-mutants developed fine twitching in the neck around P18, which was $2-3$ d earlier than twi mice, and shortly after developed a coarse tremor that gradually spread from the neck to the trunk. When they became moribund, $t w i+o p$ mice were paralyzed in the hind limbs, while twi mice developed spastic paresis. The median survival of twi+op mice was significantly shorter than that of twi mice (Fig. 1C). The life span of twi mice in this study (51 d) was longer than that in previous reports using twi mice on the original B6 background (35-40 d). This is likely because the new hybrid background derived from B6 (twi colony) and B6C3 (op colony) interacted with twi phenotypes. Altered longevity and clinical courses have been reported when the background of twi mice was altered (Duchen et al., 1980; Biswas et al., 2002; Tominaga et al., 2004; Rafi et al., 2005).

\section{The absence of CSF-1 blocks invasion of macrophages but} worsens demyelinating pathology in GLD

Microglia, CNS resident macrophages, share most of their biological properties with macrophages and transform into an activated/phagocytic state in GLD that makes it difficult to distinguish them from blood-born macrophages. Therefore, in this article the term macrophage will be used to represent these two monocytic populations, if not otherwise explicitly defined.

Our previous study showed that op mice had significantly reduced numbers of microglia in the white matter of the brain and spinal cord (Kondo and Duncan, 2009). To determine whether this reduction was applicable to the CNS-migrating macrophages in GLD, we examined the macrophage accumulation and demyelinating pathology in twi+op mice. Consistent with our previous study, $o p$ mice had remarkably decreased numbers of microglia in the white matter of the brain (Fig. $2 A$ ) and
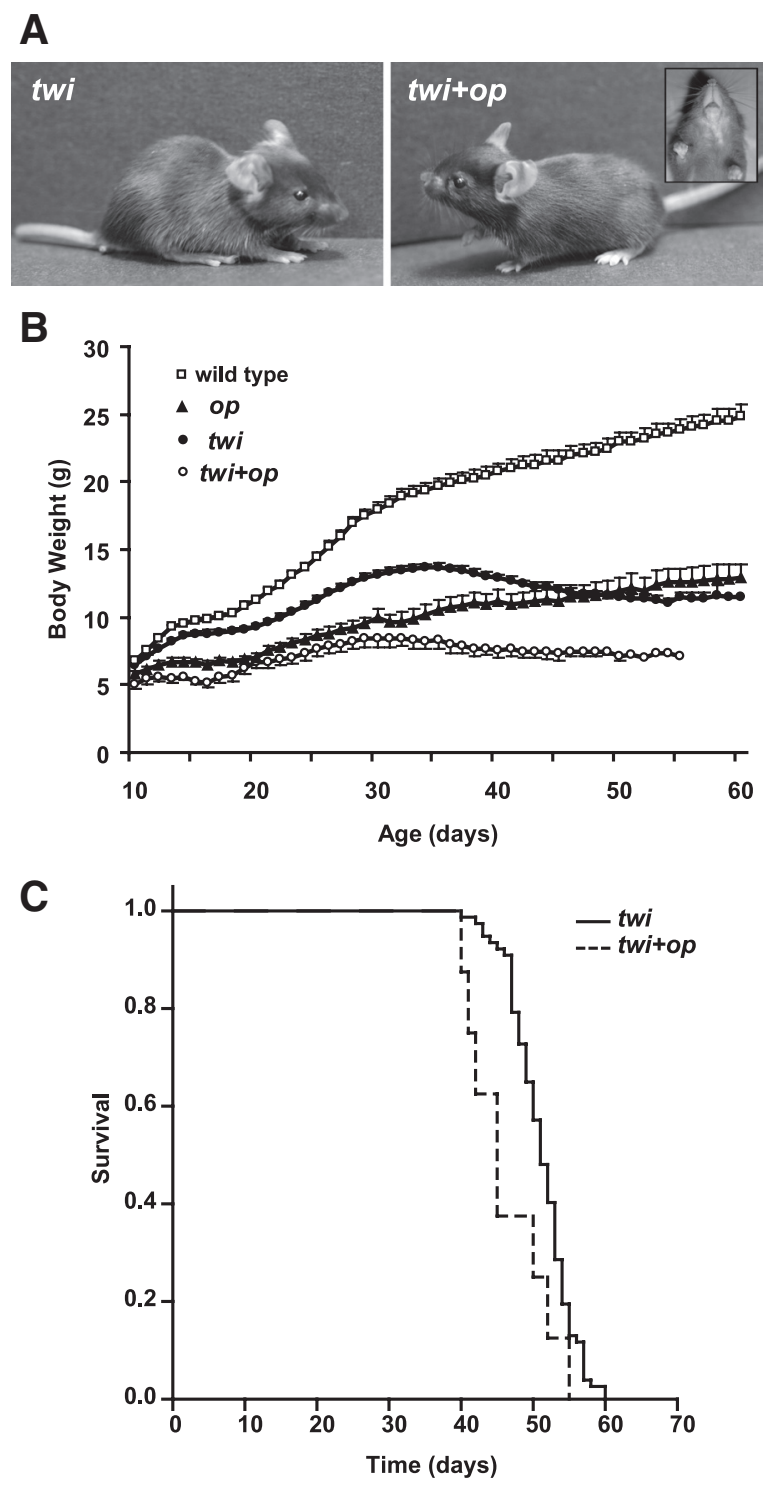

Figure 1. Clinical phenotypes of the twi+op double mutant mouse. $\boldsymbol{A}$, Physical features of twi (left) and twi + op (right) mice at P23. Note the domed scull and lack of incisors (inset) in the double mutant. $\boldsymbol{B}$, Growth curves of wild-type $(n=18)$, op $(n=13)$, twi $(n=1-55)$, and twi+op $(n=1-8)$ mice. The number of animals varies for twi and twi+op mice because of their deaths in this period. If more than three, the data are expressed as mean \pm SD. The body weight of twi and twi + op mice peaked at P35 and P29-33, respectively, and then declined along with exacerbated neurological symptoms. C, Survival curves of twi and twi + op mice. Life span of twi + op mice ( $45 \pm 2.1 \mathrm{~d}, n=8$ ) was significantly shorter than that of twi mice ( $51 \pm$ $0.7 \mathrm{~d}, n=77$, median value $\pm \mathrm{SD} ; p=0.016$, Kaplan-Meier log-rank analysis).

the spinal cord (Fig. 2B) compared with wild-type mice. The white matter of $t w i$ mice was filled with a large number of macrophages by $\mathrm{P} 45$ (Fig. 2). However, this macrophage infiltration was almost completely absent in the twi+op double mutant (Fig. 2).

The lack of macrophages did not influence myelin development in op mice (Figs. 2 B, 3) (Kondo and Duncan, 2009). Demyelinating pathology in the white matter appeared to be more severe in twi+op mice than in twi mice (Fig. 2). Quantitative analyses of myelin showed that there was no significant difference in the number of intact axons among the genotypes within the same age groups (Fig. $3 A$ ). The occurrence of myelin degeneration was significantly higher in $t w i$ and $t w i+o p$ mice compared to the wild-type control from P30 through P45, and there was no difference between these two mutants (Fig. 3B). However, 
A

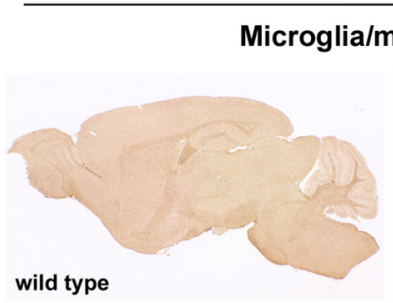

\section{wild type}

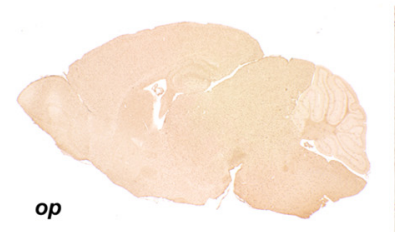

op
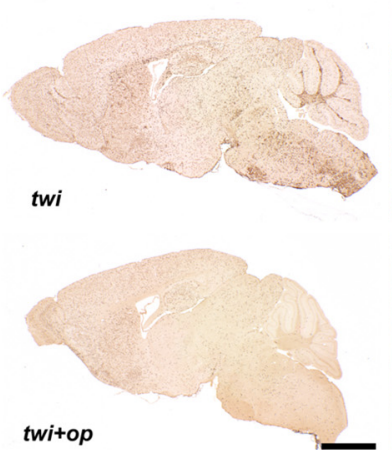

Brain
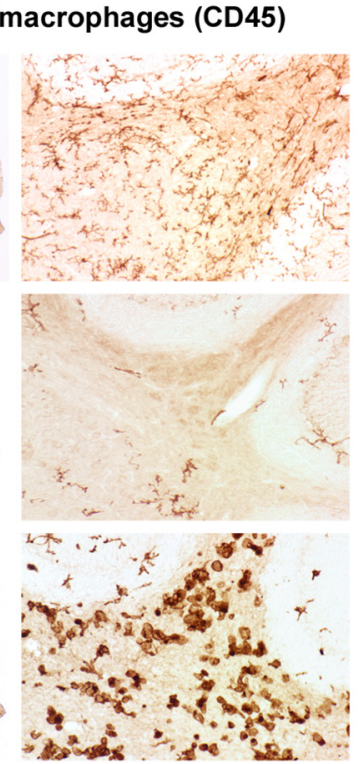

B

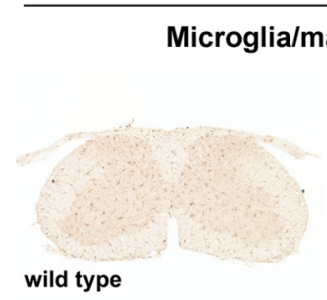

wild type

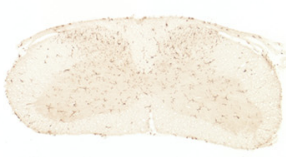

op

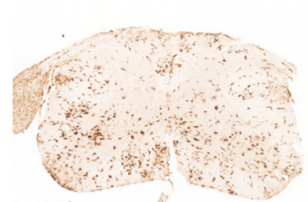

twi
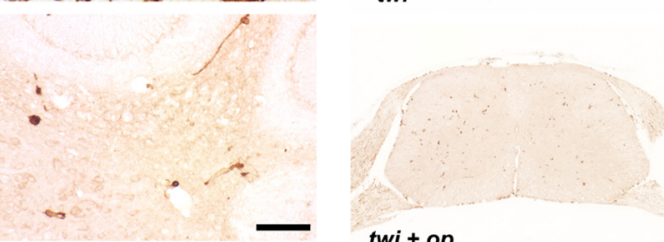

Spinal cord
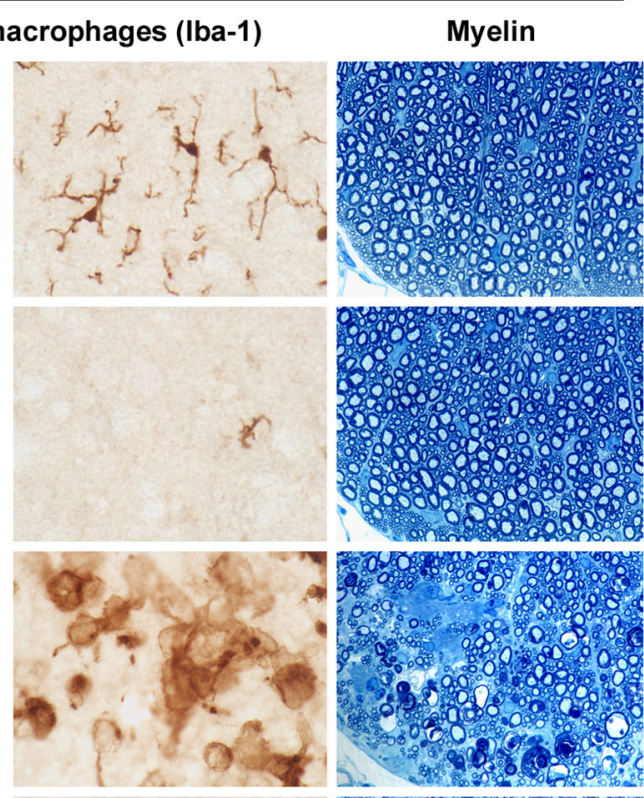

twi $+o p$
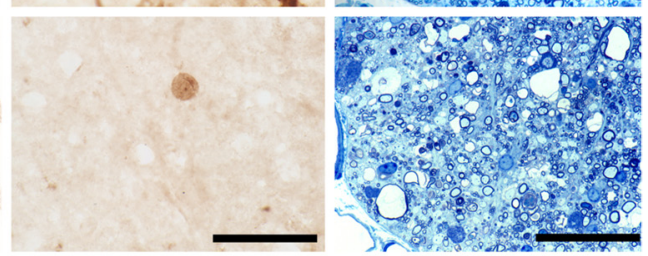

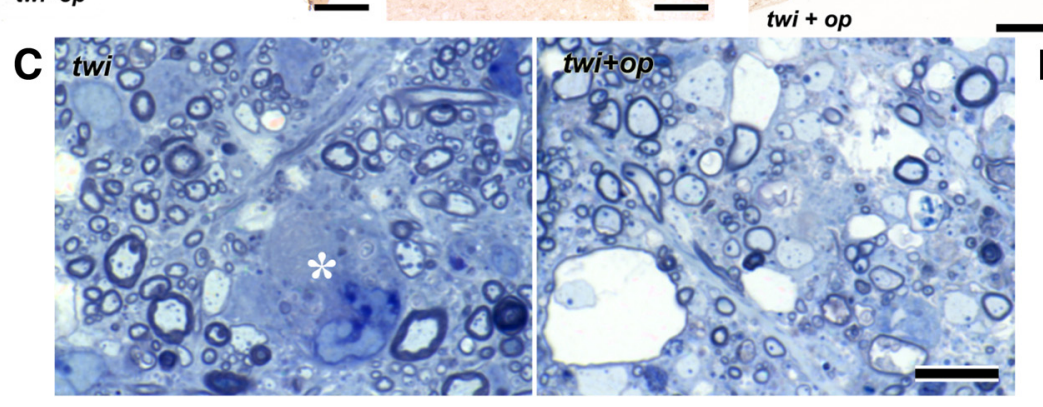

D

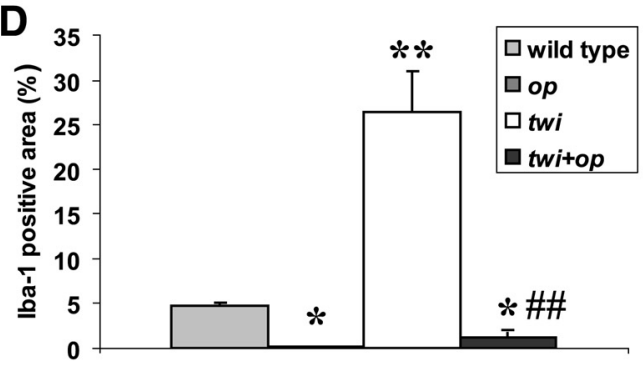

Figure 2. The absence of macrophages in twi mice leads to severe myelin pathology. $A, C D 45$-immunoreactive microglia and macrophages in sagittal brain sections of 45 -d-old mice. Right panels show the cerebellar white matter at a higher magnification. Numerous macrophages in the twi white matter were absent in twi + op mice. $\boldsymbol{B}$, Iba-1-immunoreactive microglia and macrophages (left and middle panels) and toluidine blue-stained myelin in the cervical spinal cord of 45-d-old mice. Middle and right panels are taken from the ventral white matter at a higher magnification. $C$, Details of the demyelinating pathology demonstrates loss of myelin, degenerated myelin, and thinly myelinated fibers both in twi (left) and twi+op (right) mice. The asterisk indicates a globoid macrophage. More demyelinated axons were seen in $t w i+$ op mice than in twi mice. $\boldsymbol{D}$, Comparison of the lba-1-immunoreactive areas in the ventral white matter of the spinal cord, showing that the accumulation of macrophages was significantly reduced in twi+ op mice compared with twi mice. One-way ANOVA was followed by Scheffé's $F$ test; ${ }^{*} p<0.05$, ${ }^{* *} p<0.01$ compared with wild-type mice; ${ }^{\# \#} p<0.01$ compared with twi mice. Scale bars: $\boldsymbol{A}$, left panels, $2 \mathrm{~mm} ; \boldsymbol{A}$, right panels, $100 \mu \mathrm{m} ; \boldsymbol{B}$, left panels, $0.5 \mathrm{~mm} ; \boldsymbol{B}$, middle and right panels $50 \mu \mathrm{m} ; \boldsymbol{C}, 10 \mu \mathrm{m}$.

twi+ op mice had significantly more nonmyelinated axons at $\mathrm{P} 45$ (Fig. 3C). The average diameter of myelinated axons increased with age in all genotypes, except that the diameter in $t w i$ and twi+op mice dropped at P45 and was significantly smaller than that in the wild-type control (Fig. 3D). This reduction was due to a preferential loss of myelin in large diameter axons (data not shown). At P40 and P45, the thickness of myelin was significantly less both in twi and twi+op mice compared with wild-type mice (Fig. $3 E$ ) for the same reason (i.e., thick myelin was preferentially lost). When the G-ratio was calculated, twi and twi $+o p$ mice had significantly larger G-ratios at P40 and P45 (indicative of thinner myelin relative to the size of axon) compared with wild-type mice (Fig. $3 F$ ). At P30, the G-ratio of twi+op mice was significantly larger than both $t w i$ and wild-type mice (Fig. $3 F$ ). As a result, only the twi+op genotype showed the sustained high G-ratio for life, indicating that in twi+op mice the thickening of myelin is sup- pressed. It is interesting that the development (wrapping) of myelin from P15 to P30 was not affected in either the op or twi genotype alone. The importance of macrophage/microglia in myelin development may be inconspicuous in normally developing CNS. However, certain pathological environments, e.g., GALC deficiency in this study, may reveal the significance of these cells in supporting myelination.

A unique histological feature of GLD is the presence of PASpositive macrophages, so-called "globoid cells," in demyelinated lesions. We regarded this PAS-positive material as an indicator of myelin phagocytosis, because macrophages turn PAS positive when they phagocytose galactosylceramide, a cerebroside native to myelin sheath (Austin and Lehfeldt, 1965). Degenerated myelin was frequently observed in the white matter parenchyma in twi op mice (Fig. $4 A-D$ ); however, in parallel with the reduction in the number of macrophages, PAS stain was rarely found in the 
A

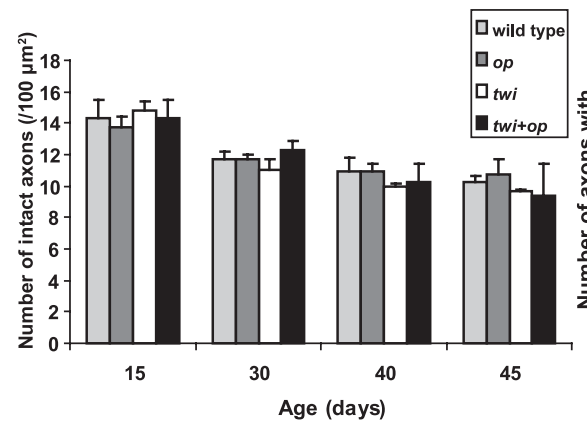

B
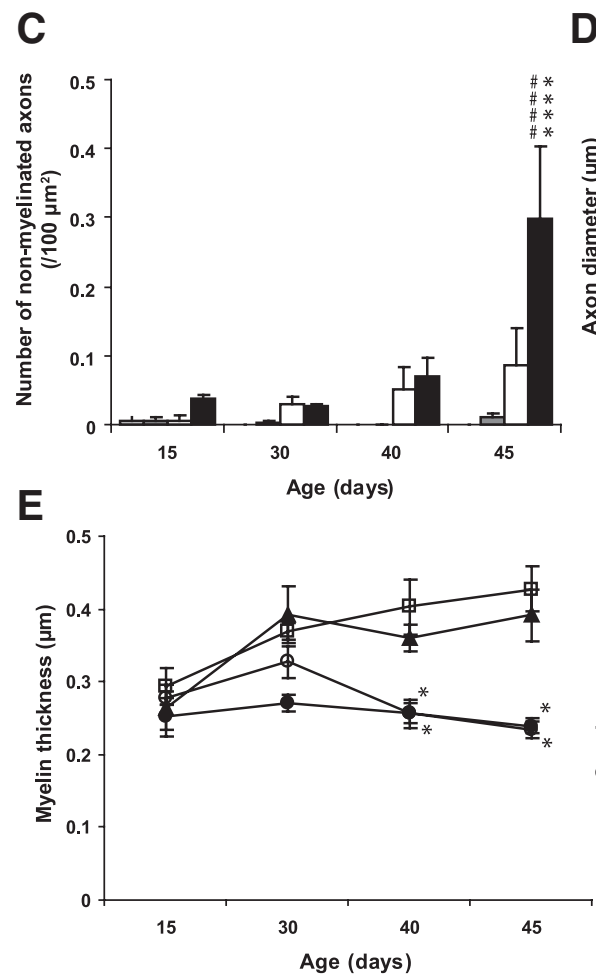

$\mathbf{E}$

Figure 3. Chronological alteration of myelin pathology in the ventral white matter of the cervical spinal cord of the mutant mice. $\boldsymbol{A}$, There was no significant difference in the number of intact axons among the genotypes within the same age groups. $\boldsymbol{B}$, The number of axons that had degenerating myelin significantly increased both in twi and twi + op mice compared with age-matched wild-type control after P30, but there was no significant difference between the two groups. C, The number of nonmyelinated axons increased with age in both twi and twi + op mice and reached a significant level compared with wild-type control in P45 twi o op mice. The number was significantly higher in twi $+o p$ mice than in twi mice at P45. D, Average diameter of myelinated axons decreased in twi and twi + op mice at P45 mainly due to preferential demyelination of large-diameter axons. $\boldsymbol{E}$, Average thickness of myelin decreased in twi and twi + op mice at P40 and P45 compared with wild-type control. Growth of myelin was obvious in twi mice at $\mathrm{P} 30$, while myelin thickness in twi + op mice remained small. $\boldsymbol{F}$, Average $\mathrm{G}$-ratios of myelinated fibers. At P40 and P45, the G-ratios were significantly higher in twi and twi + op mice compared with the wild-type mice. At P30, the G-ratios of twi mice were not different from those of wild-type control, whereas twi + op mice showed significantly higher G-ratios compared with both wild-type and twi mice. There was no significant difference between wild-type and op mice in $\boldsymbol{A}-\boldsymbol{F} .{ }^{*} p<0.05,{ }^{* *} p<$ 0.01 , and ${ }^{* * * *} p<0.0001$ compared with wild-type mice, and ${ }^{\# \#} p<0.01$ and ${ }^{\# \# \# p} p<0.0001$ compared with twi mice within the same age groups [one-way ANOVA followed by Scheffé's F post-hoc test $(\boldsymbol{A}-\boldsymbol{E})$ and the Kruskal-Wallis test $(\boldsymbol{F})$ ].

twi+op white matter (Fig. $4 E, F$ ). The PAS-positive area occupied $12.7 \pm 3.8 \%$ of the ventral white matter in $t w i$ mice, whereas it was significantly reduced to $0.3 \pm 0.1 \%$ in $t w i+o p$ mice $(p<$ 0.05 , Student's $t$ test, $n=3$ per group).

Introduction of the CSF-1 $1^{o \text { Pop }}$ mutation into the twi mouse effectively blocked macrophage infiltration in the CNS (Fig. 2). Interestingly, however, the extent of macrophage accumulation in the peripheral nerves showed no difference between $t w i$ and twi+op mice (Fig. 5A,B). The sciatic nerves were severely demy- elinated in twi and twi+op mice, and to the same extent (Fig. $5 A, C, D$ ).

The white matter of $t w i+o p$ mice shows similar reactive astrocytosis to $t w i$, but has a smaller OPC population and fewer OLs

To determine whether the CSF-1 $1^{\text {op } / o p}$ mutation affects other cell populations, astrocytes, OPCs, and OLs were immunolabeled for anti-GFAP, NG2, and GST- $\pi$ antibodies, respectively (Fig. 6). Immunoreactivity of these markers appeared to be the same between wild-type and $o p$ mice. $\mathrm{GFAP}^{+}$astrocytes were highly activated in the affected white matter of twi and twi+op mice, and to the same extent (Fig. 6A). However, quantitation of astrocyte numbers was difficult because GFAP immunoreactivity was too abundant in the spinal cord, and astrocytes in the spinal cord are fibrous rather than "star shaped." Thus, to quantitatively compare the GFAP expression levels, we relied on the densitometry of GFAP immunoreactivity in the white matter and also gene expression analysis. GFAP immunoreactivity in twi and twi+op mice significantly increased compared with the wild-type mice (Fig. $6 B$ ). GFAP mRNA levels also significantly increased $5.9 \pm 1.0$ - and $5.0 \pm 0.9$-fold in twi and twitop mice compared to wildtype mice, respectively (no significant difference between the two) (Fig. 7A). NG2 ${ }^{+}$ cells, which represent a large population of OPCs, had a small cell body and well branched fine processes in the white matter of wild-type and op mice (Fig. 6). These cells became hypertrophic with short and stout processes in twi and $t w i+o p$ mice. It appeared that the number of such OPCs remained the same in $t w i+o p$ mice as in wild-type mice. In twi mice, their quantitation was difficult, because NG2 immunoreactivity was also found in some macrophages (Fig. 6, arrowheads). While NG2 is widely recognized as a marker for OPCs, NG2 immunoreactivity has been found also on CD68- and CD11b-positive human microglia in vitro and in vivo (Pouly et al., 1999 ) and on rat macrophages in the injured spinal cord (Jones et al., 2002). When $\mathrm{NG}_{2}{ }^{+}$OPCs were counted by excluding the $\mathrm{NG}^{+}{ }^{+}$ macrophage-like cells, the number of OPCs significantly increased in twi mice compared with wild-type mice (Fig. 6C). In contrast, the number of OPCs in twi+op mice did not change from the normal level (Fig. 6C). To support this finding, we estimated the OPC population using quantitative RT-PCR for platelet-derived growth factor receptor $\alpha$ (PDGF-R $\alpha$ ) mRNA expression, which significantly increased in twi mice $(2.2 \pm 0.3-$ fold, $p<0.0094)$ but remained unchanged in $t w i+o p$ mice $(1.0 \pm$ 


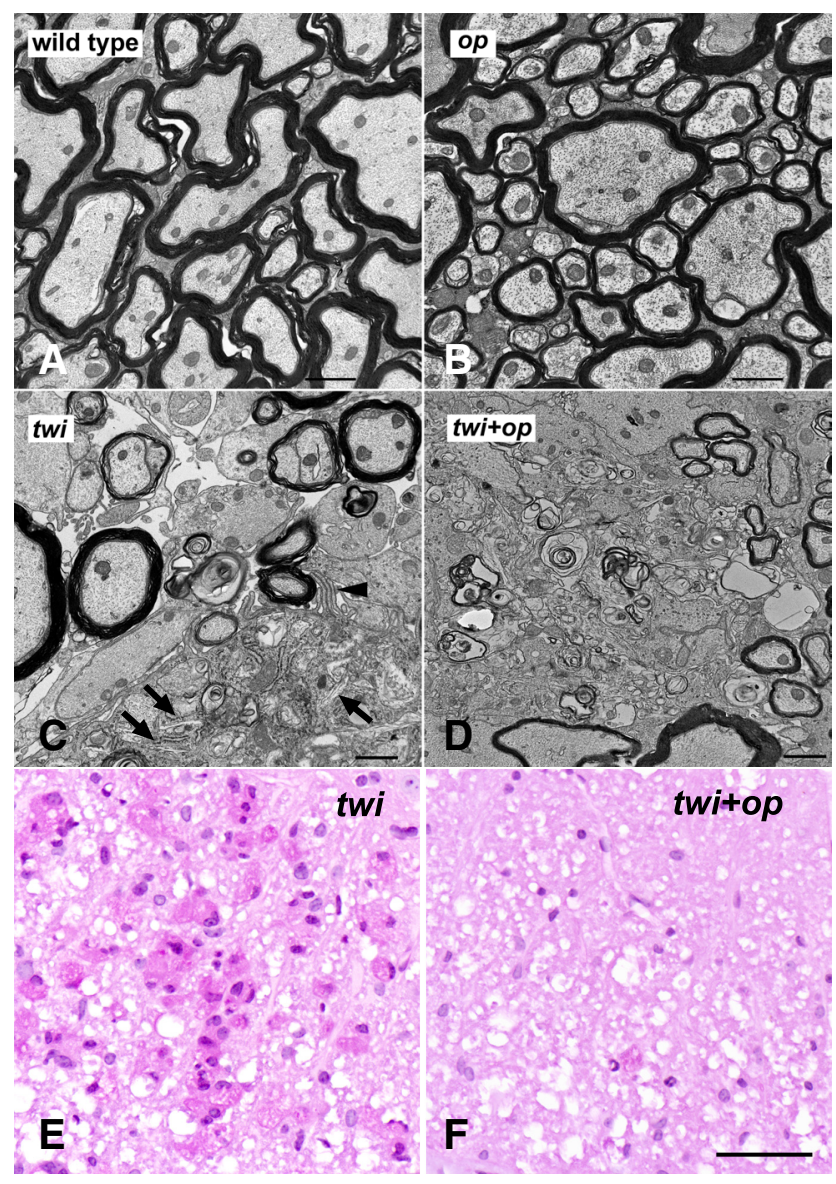

Figure 4. Myelin phagocytosis is compromised in the twi+op mutant. $\boldsymbol{A}-\boldsymbol{D}$, Representative electron micrographs from the ventral white matter of the cervical spinal cord demonstrate that myelination in op mice was comparable to that in wild-type mice $(\boldsymbol{A}, \boldsymbol{B})$, myelin debris was actively cleared by a macrophage (occupying lower right corner) showing pseudopodia (arrowhead) and tubular inclusion bodies (arrows) (C), and that nonphagocytosed myelin debris (arrows) was frequently observed in the white matter parenchyma of twi+op mice (D). $E, F$, PAS staining in the ventral white matter of the cervical spinal cord shows numerous macrophages that contain PAS-positive material in twi mice at P45 $(\boldsymbol{E})$, whereas the numbers are few (arrowhead) in twi+ op mice (F). Scale bars: $\boldsymbol{A}-\boldsymbol{D}, 1 \mu \mathrm{m} ; \boldsymbol{E}, \boldsymbol{F}, 50 \mu \mathrm{m}$.

0.0 -fold; significantly different from twi mice with $p<0.0136$ ) (Fig. 7A). GST- $\pi$ has been a marker for mature OLs (Tansey and Cammer, 1991). Although there were areas of patchy loss of OLs in twi mice (Fig. 6, asterisk) that appeared to coincide with clustered macrophages, the population of OLs was not much affected in the other areas. By contrast, we found fewer GST- $\pi^{+}$OLs with a typical oval cytoplasm in twi+op mice (Fig. 6, arrows). Instead, we saw a number of small GST- $\pi^{+}$fragments diffusely spread in the white matter, which could possibly be fragmented myelin and OL processes. As we were not certain what these fragments in twi + op mice represented, we counted only GST $-\pi^{+}$cells containing a nucleus and found that the number of GST- $\pi^{+}$OLs moderately but significantly decreased in twi mice compared with wild-type mice (Fig. 6D). GST- $\pi^{+}$OLs in twi+op mice further deceased in number, and the differences were significant compared with twi mice as well as wild-type mice (Fig. 6D). We also quantified mRNA levels for myelin proteins to estimate the population of OLs. mRNA expressions of the proteolipid protein (PLP)/DM20 and PLP-specific genes decreased in $t w i$ mice and further decreased in $t w i+o p$ mice (Fig. $7 A$ ). The difference from the wild-type control reached statistical significance only for twi + op mice, likely due to the small sample size or that the re- duction in the number of OLs could be more than the mRNA value because of possible compensation by upregulated mRNA synthesis in response to active remyelination. MBP mRNA levels showed similar changes, and twi+op mice showed significantly lower levels than twi mice $(p<0.0396)$.

Brain psychosine levels elevated both in twi and twi+op mice GALC-defective OLs and Schwann cells in GLD are unable to degrade its substrate, galactocerebroside. Unlike other lysosomal storage diseases, however, storage of galactocerebroside in the myelinating cells does not occur while psychosine, a cytotoxic lipid metabolite, accumulates and kills these myelinating cells, leading to demyelination (the psychosine hypothesis) (Miyatake and Suzuki, 1972). We questioned whether this accumulation of psychosine also occurs in the macrophage-deficient condition and determined the levels of psychosine and free sphingosine in the mutants using HPLC. The levels of psychosine significantly increased in the forebrain of both $t w i$ and $t w i+o p$ mice compared to wild-type mice (Table 2 ). Interestingly, twi + op mice had significantly lower psychosine levels when compared with twi mice (by $28 \%$ ). Thus, the levels of psychosine did not correlate with the severity of disease. However, the decreased psychosine levels in twi $+o p$ mice may be a reflection of the decreased number of OLs or myelin turnover, as suggested by the reduction in mRNA levels of myelin proteins (reduction against twi mice: PLP, by $44.5 \%$; MBP, by 34.2\%) (Fig. 7A).

Both $t w i$ and $t w i+o p$ mice had significantly lower levels of free sphingosine compared to the wild-type control. The levels were significantly lower in twi+op mice compared with $t w i$ mice. Sphingosine is a source of sphingolipids that are highly bioactive and essential as structural components of cell membranes and lipoproteins and as regulators of a variety of cellular functions such as cell migration, proliferation, differentiation, signaling, and death (Futerman and Hannun, 2004; Hannun and Obeid, 2008). Therefore the metabolism of these complex and diverse compounds must be strictly controlled (Merrill, 2002). At present, the mechanism for the decreased level of sphingosine as well as its clinical significance is unclear. However, it is highly likely that the metabolism of the sphingolipid family may be disturbed by psychosine overproduction (White et al., 2009) and/or the decreased sphingosine levels in GLD.

\section{Quantitative gene expression analyses}

Macrophages found in the white matter of GLD are morphologically unique; they have a large plump cytoplasm, are often multinucleated, and contain tubular inclusion bodies (Yunis and Lee, $1969,1970)$. To characterize the inflammatory profiles in GLD and determine how it is affected by the absence of macrophages, we performed real-time RT-PCR and analyzed the changes in the gene expression of molecules that regulate inflammatory environment and of cell-specific markers on macrophages and T cells in the spinal white matter of $t w i$ and $t w i+o p$ mice at P45. Among the molecules related to inflammation examined (Fig. $7 B$ ), a large increase ( $>30$-fold) was seen in TNF- $\alpha$ and arginase- 1 mRNAs in twi mice $(37.8 \pm 10.2$ - and $29.3 \pm 2.2$-fold compared with wildtype, respectively). The elevation of these molecules was drastically downregulated in twi+op mice (by 93.4 and $84.4 \%$ for TNF- $\alpha$ and arginase- 1 , respectively). TNF- $\alpha$ not only works as a destructive proinflammatory cytokine but also promotes proliferation of OPCs and remyelination (Arnett et al., 2001). In addition, arginase- 1 is an enzyme known to synthesize polyamines that counteract myelin inhibition of axon growth in vitro (Cai et al., 2002). Thus, some aspects of macrophage function in twi mice 

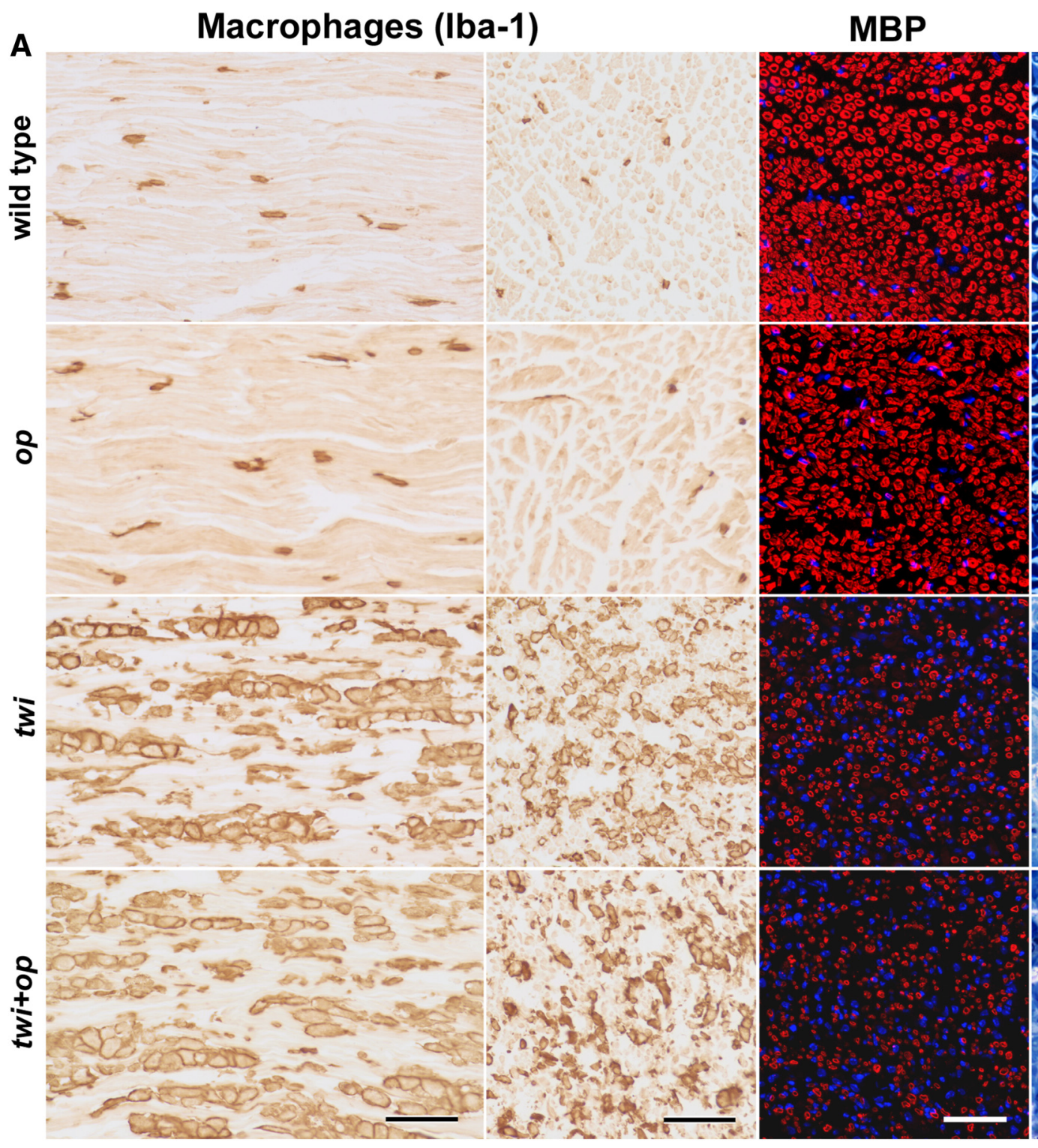

Toluidine blue
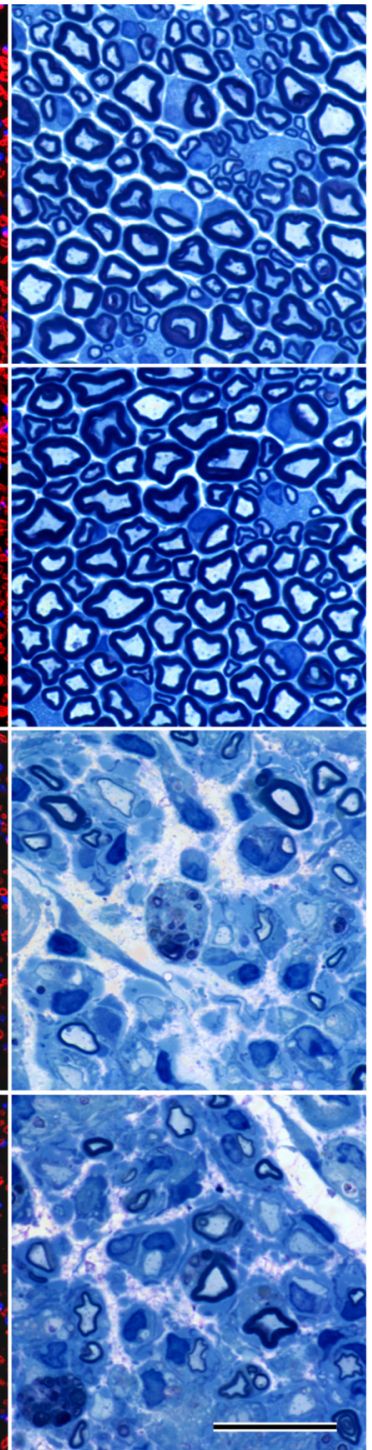

B

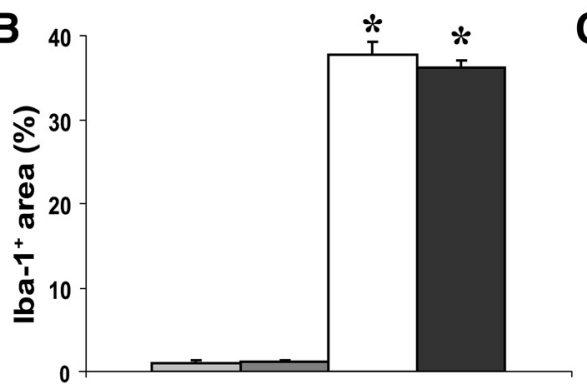

C

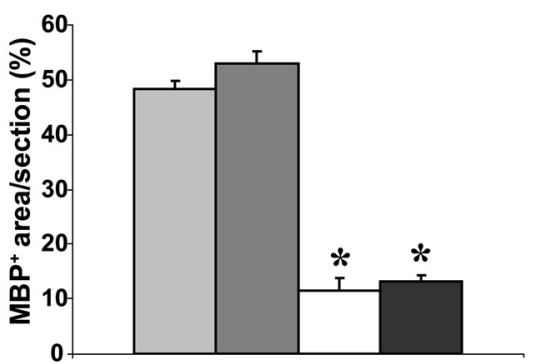

D $\frac{\Phi}{6}$

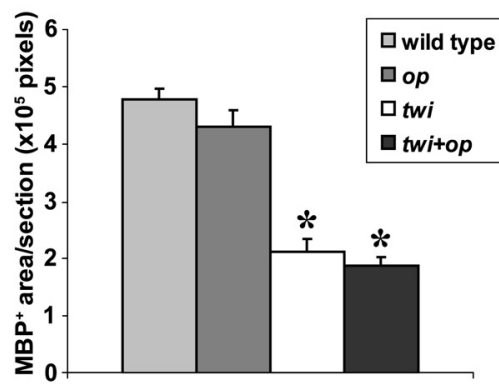

Figure 5. Invasion of macrophage is not inhibited in the peripheral nerves of twi + op mice. $\boldsymbol{A}-\boldsymbol{D}$, Iba-1 immunolabeling in the longitudinal section $(\boldsymbol{A}$, far left column) and cross-section $(\boldsymbol{A}$, second column from left) of the mid-sciatic nerve revealed that the macrophage distribution is similar between wild-type and op mice at P45. The nerves of twi and twi + op mice contained a significantly greater degree of macrophage accumulation than wild-type mice $(\boldsymbol{B})$, but there was no difference in the extent of accumulation between twi and twi + op mice $(p=0.3002)$. Also note that, unlike the CNS white matter, macrophages in op mice populated the nerve to the same extent as those in the wild-type control. Immunohistochemistry for MBP in cross section of the nerve $(\boldsymbol{A}$, third column from left) showed that twi and twi + op mice had similar and significant losses of myelin $(\boldsymbol{C}, \boldsymbol{D})$. To avoid a potential misinterpretation due to the hypertrophy in the twi and twi $+o p$ nerves, the data were presented as the percentage $\mathrm{MBP}^{+}$area $(\boldsymbol{C})$ and $\mathrm{MBP}^{+}$area per section $(\boldsymbol{D})$; however, significant volume effects were not observed. Toluidine blue myelin staining at a higher magnification demonstrated demyelinated and remyelinated axons surrounded by increased extracellular matrix and endoneurial edema ( $\boldsymbol{A}$, far right column) in both twi and twi + op mice. Sections were cut at 6 and $1 \mu \mathrm{m}$ for immunostaining and toluidine blue staining, respectively. Scale bars: 100,50, and $20 \mu \mathrm{m}$ for the lba-1, MBP, and toluidine blue stainings, respectively. One-way ANOVA was followed by Scheffe's $F$ test; ${ }^{*} p<0.0001$ compared with wild-type mice ( $n=3$ per group). 
may promote myelin repair, and this was absent in twi+op mice. mRNA expression for leukemia inhibitory factor (LIF), which is produced by astrocytes and promotes myelination (Ishibashi et al., 2006), increased both in twi $(17.5 \pm 2.4$-fold $)$ and twi+op $(8.8 \pm 2.9$-fold $)$ mice, although the increase for $t w i+o p$ mice did not reach a significant level, and there was a significant difference between twi and twi + op mice $(p=0.0322)$. Expressions of TGF- $\beta$, IL- 6 , iNOS, and IGF-1 mRNA were all mildly but significantly increased in twi mice (4.7- to 8.4-fold) and were significantly reduced in twi+op mice compared with twi mice.

It has been reported that not all cells of monocyte lineage, dendritic cells in particular, are dependent on CSF-1 in vivo (Witmer-Pack et al., 1993). Thus, we determined phenotypic characteristics of monocytic cells recruited in the twi CNS and their alterations in twi+op mice (Fig. 7C). CD11c mRNA in twi mice increased $243.7 \pm 33.0$-fold compared with wildtype mice. It also increased in twi+op mice. However, the level was significantly less by $92.1 \%$ compared to that in $t w i$ mice. CD $11 \mathrm{~b}$ and CD16 (Fc $\gamma$ receptor III) mRNAs in twi mice increased over 10-fold over wild-type mice but showed no increase in twitop mice. CD80, CD86, CD206 (mannose receptor), and MHC II mRNAs moderately but significantly increased (2.4- to 6.1-fold) in twi mice but returned to the control levels in twi+op mice.

In twi mice, mRNA for CD3, a pan-T cell marker, increased only $3.1 \pm 0.9$-fold ( $p=0.0130$ ) (Fig. 7D). Between CD4 and CD8 mRNAs, the increase was relatively CD4 dominant $(13.2 \pm 1.8$ - versus $4.9 \pm$ 1.0-fold, respectively). CD28 (B7 receptor) mRNA was highly increased in twi mice $(20.1 \pm 1.3$-fold $)$. There was a significant but small increase in mRNA for FoxP3, a marker for regulatory T cells $(~ p=0.0398)$. In twi+op mice, mRNA levels for these $\mathrm{T}$ cell surface markers were significantly lower than the levels in twi mice and not different from the levels in the wild-type control. Increased mRNA levels for CD4 and CD8 have also been reported in the brain and spinal cord of a transgenic mouse model of GLD (Luzi et al., 2009). Unlike in experimental autoimmune encephalomyelitis, an animal model of multiple sclerosis, involvement of $\mathrm{T}$ cells in the demyelinating pathophysiology appears to be minor in GLD, at least histologically (Ohno et al., 1993; Matsushima et al., 1994). Indeed, gene expression for MHC II, a key molecule for antigen presentation, and the CD3 pan-T cell marker were upregulated only to a minor extent, even though other antigen presentation-related molecules on the macrophage (CD80, CD86) and T cell (CD28) were much more upregulated. Moreover, a recent study has shown that the development of $\mathrm{T}$ cells in the lymphoid organs is impaired along the disease progression in twi mice that causes lymphocytopenia in the periphery (Galbiati et al., 2007), suggesting that $\mathrm{T}$ cellmediated immunity may be compromised in the twi CNS. Therefore, actual contribution of T cells to the demyelination in GLD needs to be further investigated.

\section{Both M1 and M2 macrophage markers are upregulated in twi mice}

It is not clear whether the differences in the levels of gene expression between $t w i$ and twi+op mice (Fig. 7) arise from the difference in the number of macrophages or from any phenotypic changes in individual macrophages. Recently, efforts have been made to separate destructive and protective phenotypes of macrophages (so called M1 and M2 phenotypes, respectively) using distinct molecular markers. The former includes iNOS, CD16, and CD86, and the latter includes arginase-1 and CD206 (Gordon, 2003; Mantovani et al., 2005; Popovich and Longbrake, 2008; Kigerl et al., 2009). To determine whether and how such phenotypic changes occur in individual macrophages of $t w i$ and $t w i+o p$ mice, we further investigated the immu- 


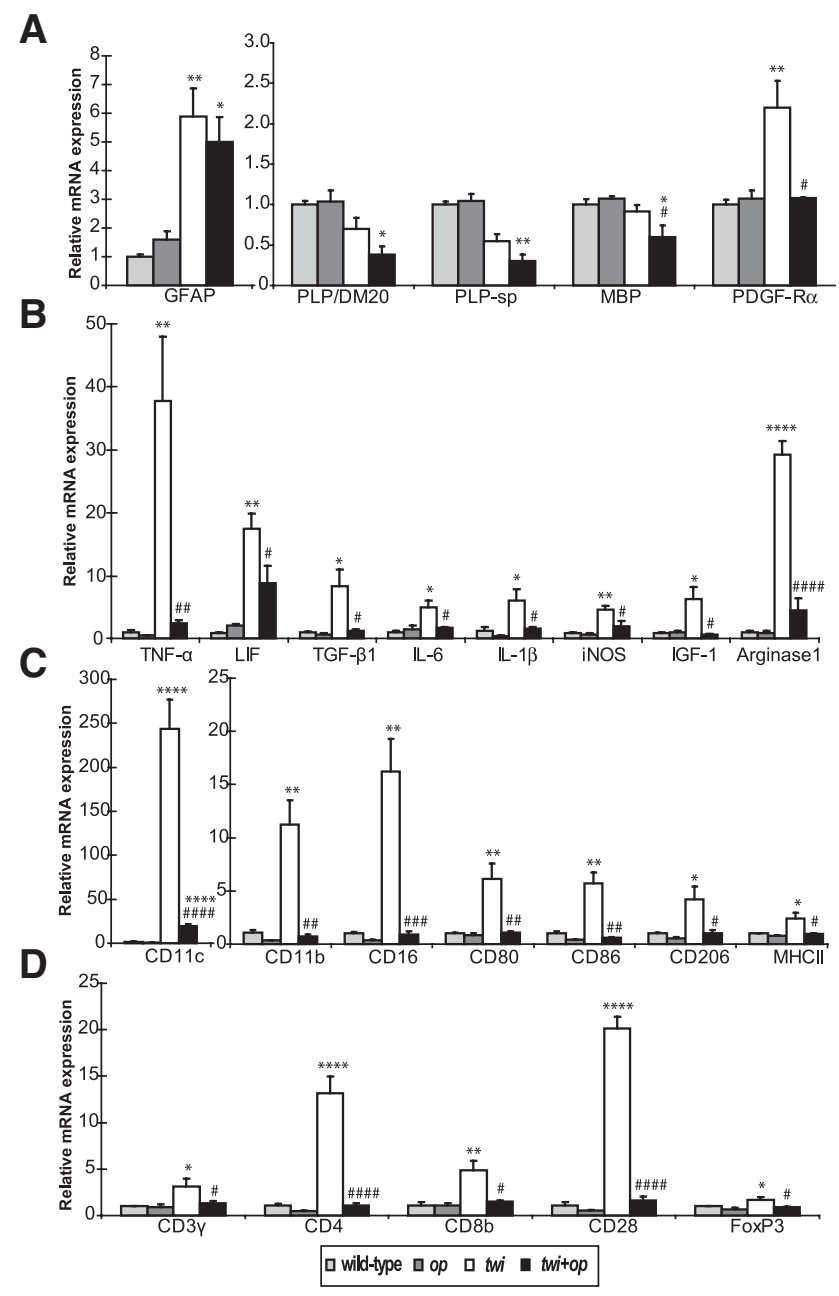

Figure 7. $\boldsymbol{A}-\boldsymbol{D}$, Quantitative real-time RT-PCR analyses for mRNA expression levels in the cervical spinal cord of 45-d-old mutants. Shown are gene expression levels relative to the levels for the wild-type control ( $n=3$ each group) for myelin proteins and markers of OPCS and astrocytes $(\boldsymbol{A})$, molecules related to inflammation $(\boldsymbol{B})$, surface makers for the cells of monocyte lineage $(\boldsymbol{C})$, and surface markers for $T$ cells $(\boldsymbol{D})$. Although op mice tended to express lower levels of mRNA in some molecules (e.g., IL-1 $\beta$, CD11b, and CD16) compared with wild-type mice, there was no significant difference between the two groups. One-way ANOVA was followed by Scheffé's $F$ test; ${ }^{*} p<0.05,{ }^{* *} p<0.01,{ }^{* * *} p<0.001$, and ${ }^{* * * *} p<0.0001$ compared with

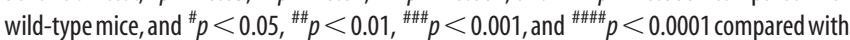
twi mice. FoxP3, Forkhead box P3; PLP-sp, primers for PLP designed to specifically detect the PLP CDNA sequence that is absent from the DM20 CDNA.

Table 2. Levels of psychosine and sphingosine in the brain.

\begin{tabular}{lll}
\hline & Psychosine (pmol/mg protein) & Sphingosine (pmol/mg protein) \\
\hline Wild type & $28 \pm 4$ & $104 \pm 11$ \\
op & $27 \pm 5$ & $107 \pm 18$ \\
twi & $328 \pm 52^{* * *}$ & $79 \pm 16^{* *}$ \\
$t w i+o p$ & $236 \pm 65^{*, \dagger}$ & $65 \pm 8^{* *, \dagger}$
\end{tabular}

Values are expressed as mean \pm SD from three animals per group at $45 \mathrm{~d}$ old. Values for each animal were an average of measurements from the right and left brain hemispheres. ${ }^{* *} p<0.001$ and ${ }^{* * *} p<0.0001$ versus wild type group; ${ }^{\dagger} p<0.05$ versus twi group; one-way ANOVA followed by Scheffé's F post-hoc test.

nohistochemical expression of M1 and M2 markers in the spinal white matter of $\mathrm{P} 45$ animals.

Arginase-1 protein levels were significantly increased in twi mice compared with wild-type mice, and this increase was significantly inhibited in $t w i+o p$ mice (Fig. $8 \mathrm{~A}$ ), although the elevation in twi mice was not as great as what was seen in the gene expression analysis (Fig. 7B). Arginase-1 was constitutively expressed in the motor neurons and axons in the ventral horn in all four genotypes (Fig. $8 B$ for the wild type; data not shown for the other genotypes). In the wild-type mice, Iba- $1^{+}$resting microglia were weakly colabeled with arginase-1 (Fig. $8 \mathrm{C}$, top, arrowheads). Microglia in $o p$ mice showed a similar appearance, except that the number was few (data not shown). In twi mice, Iba- $1^{+}$macrophages in the white matter strongly expressed arginase-1 (Fig. 8C, bottom). However the cells in the vicinity of such macrophages were found to be arginase-1 immunoreactive as well, most of which were $\mathrm{GFAP}^{+}$astrocytes (data not shown). Macrophages in twi op mice were similarly positive for arginase- 1 except that the numbers were few and there was no arginase- 1 immunoreactivity in the neighboring tissue (data not shown).

CD206 (mannose receptor)-immunoreactive cells were only weakly positive for Iba- 1 and located predominantly in the submeningeal and perivascular spaces in all four genotypes (Fig. $8 D$ for twi mice; data not shown foe the other genotypes), which is consistent with previous reports (Galea et al., 2005; Prodinger et al., 2011). Quantitation of CD206 ${ }^{+}$immunoreactivities (Fig. 8 E) showed the similar pattern with the quantitative PCR results (Fig. 7C). Interestingly, parenchymal macrophages with typical globoid cell morphology were CD206 negative in our experimental condition (Fig. $8 D$, arrows).

CD16/CD32 (Fc $\gamma$ receptor), the M1 marker, was highly expressed in submeningeal macrophages in all four genotypes (Fig. $8 F$, arrowheads). Like the M2 marker arginase-1, CD16/CD32 was weakly expressed in Iba- $1^{+}$resting microglia in wild-type (Fig. $8 F$, top) and $o p$ (data not shown) mice. Macrophages both in $t w i$ (Fig. $8 F$, bottom) and twi+op (data not shown) mice were diffusely immunoreactive for CD16/CD32. However, occasional CD16/CD32 ${ }^{+}$cells were found to be Iba-1-negative (Fig. $8 F$, arrows). The quantitative changes in $\mathrm{CD} 16 / \mathrm{CD} 32{ }^{+}$immunoreactivities (Fig. $8 G$ ) were consistent with the quantitative PCR results (Fig. 7C).

CD11c gene expression was extremely elevated in twi mice (244-fold vs wild type) (Fig. 7C) despite the fact that CD11c has been believed to initiate $\mathrm{T}$ cell-mediated pathologic conditions (Bullard et al., 2007; Chastain et al., 2011) and that T cells are rarely found in the affected white matter of GLD (Ohno et al., 1993; Matsushima et al., 1994). Therefore, in addition to the M1/M2 molecules described above we determined immunohistochemical distribution of CD11c in the spinal cord.

In the spinal white matter of wild-type and $o p$ mice, $\mathrm{CD} 11 \mathrm{c}^{+}$ cells were only sporadic and CD11b negative in our staining condition (Fig. $9 A, B$ ). The twi white matter contained a large number of CD11c cells, and they were mostly CD11b ${ }^{+}$as well (Fig. $9 A, B)$. Macrophages were few in twi+op mice. If any macrophages were present, however, such cells were almost exclusively CD $11 \mathrm{c}^{+} \mathrm{CD}_{11 \mathrm{~b}^{+}}$(Fig. 9A,B). A recent study has indicated that $\mathrm{CD} 11 \mathrm{c}^{+} \mathrm{CD} 11 \mathrm{~b}^{+}$cells exhibit immunomodulatory function and are protective against experimental autoimmune encephalomyelitis by inducing tolerance ( $\mathrm{Li}$ et al., 2008). In contrast, infiltrating $\mathrm{CD} 11 \mathrm{c}^{+} \mathrm{CD} 11 \mathrm{~b}^{+}$cells have been reported to potentiate iNOS-dependent cell death (Parajuli et al., 2010); macrophages in twi mice may also be involved in such M1 phenotypic function. Therefore further investigation needs to characterize the phenotypic uniqueness of CD11c ${ }^{+} \mathrm{CD} 11 \mathrm{~b}^{+}$macrophages in GLD.

In conclusion, both $\mathrm{M} 1$ and $\mathrm{M} 2$ macrophage markers are upregulated in twi mice, and the CSF-1 deficiency appears to cause only a reduction in the number of macrophages but not a phenotypic alteration of individual macrophages, as identified by the M1/M2 markers and CD11c. 
A
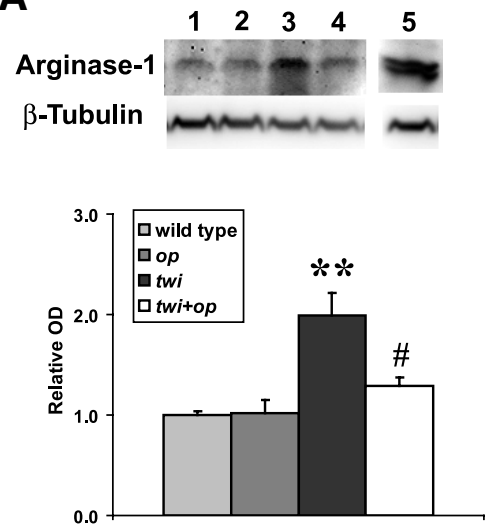

D

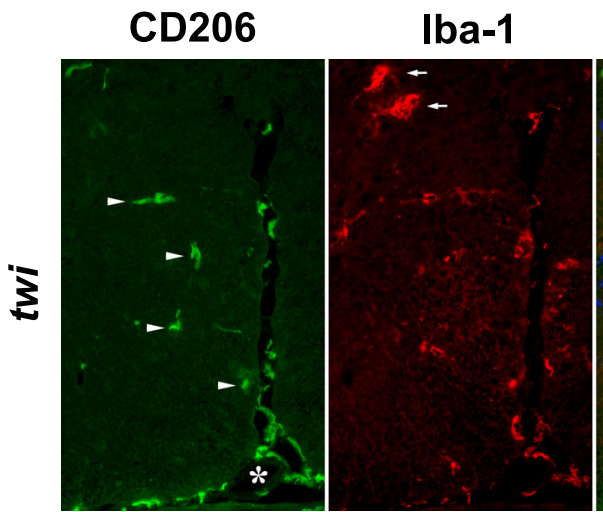

$\mathbf{F}$
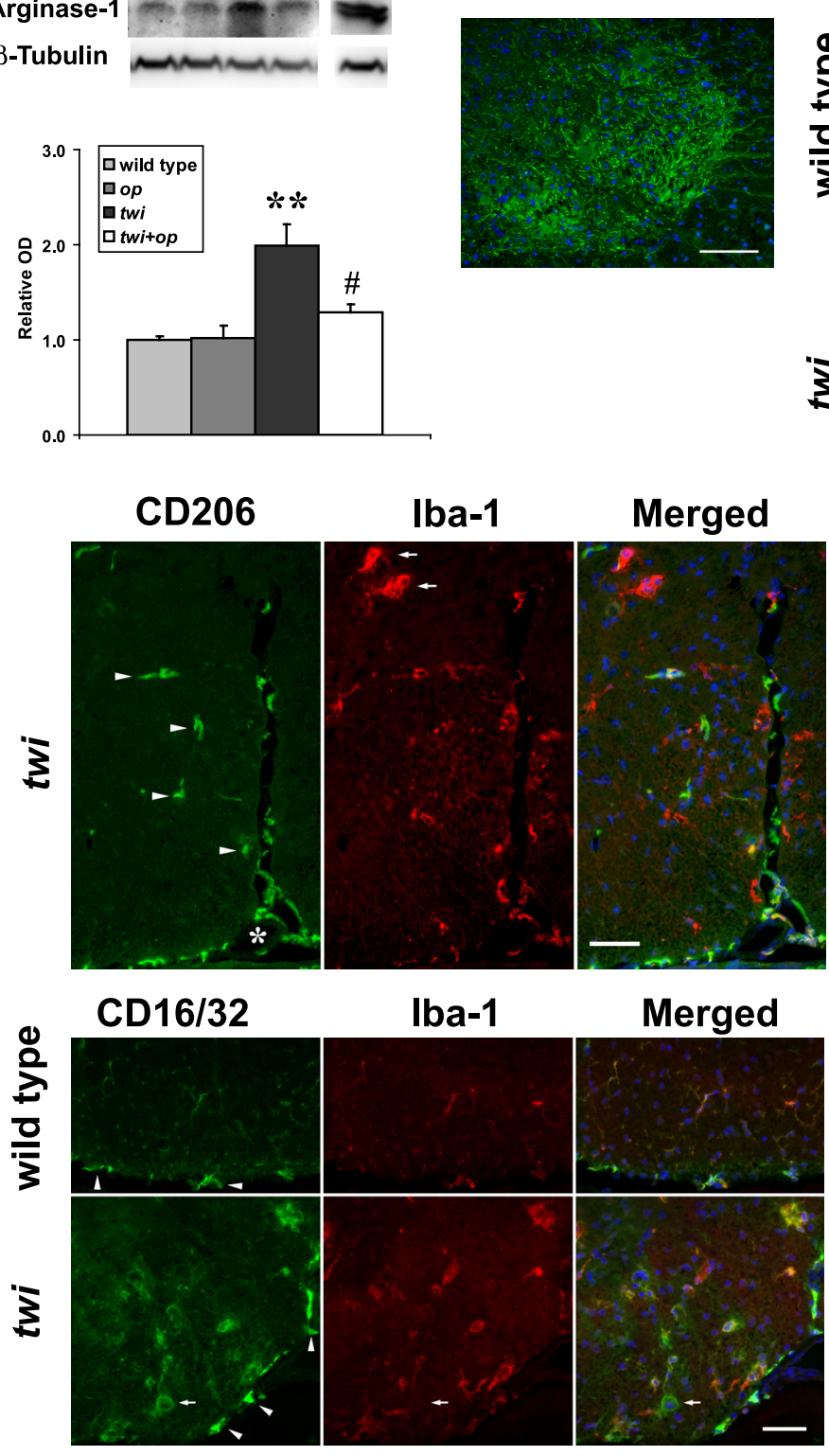

Merged

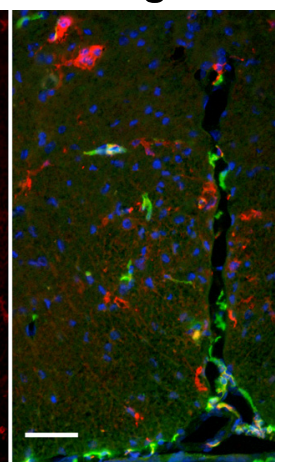

C

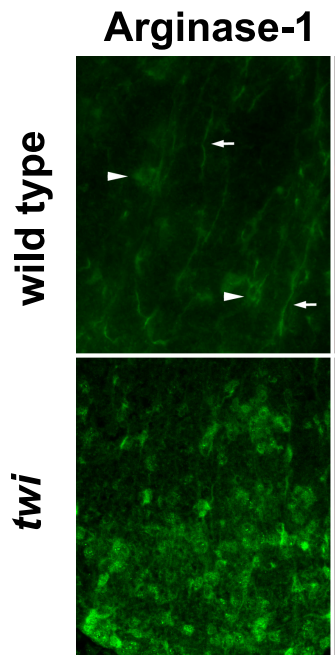

lba-1

E

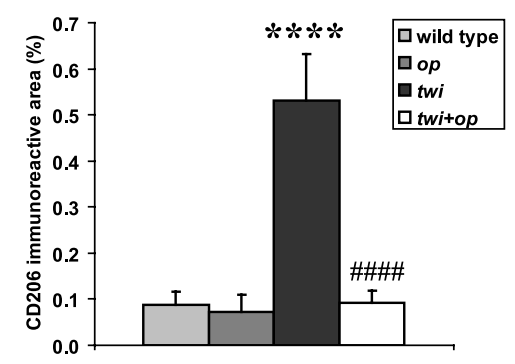

G

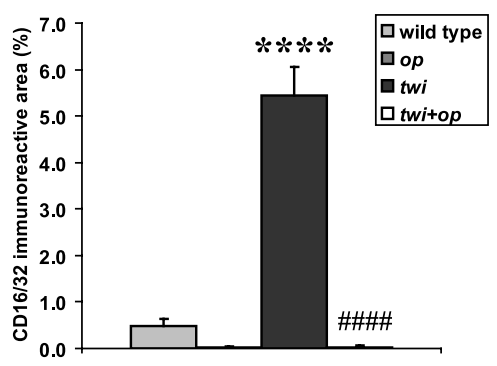

Figure 8. Macrophage markers for M1 and M2 phenotypes are upregulated and distinctively expressed in twi mice. $A$, Top, A representative Western blot analysis for protein expression of an M2 marker, arginase-1 (41 kDa), and $\beta$-tubulin ( $55 \mathrm{kDa}$; as an internal control) in the spinal cord of P45 animals. Samples are the spinal cord lysates from the following: wild-type mouse (lane 1); op mouse (lane 2); twi mouse (lane 3); twi + op mouse (lane 4); and a liver lysate from a wild-type mouse as a positive control (lane 5). Bottom, 0DS of Western blot were analyzed for argininase-1 protein expression ( $n=3$ animals per group). $\boldsymbol{B}$, Representative image of arginase-1 immunoreactivity in the ventral horn of the spinal cord in wild-type mice. Arginase-1 was intensely expressed in the soma and axon of motorneurons. C, Apartfrom the axons from the ventral horn (arrows), arginase-1 was weakly expressed in Iba- ${ }^{+}{ }^{+}$resting microglia in the wild-type control (top, arrowheads). Arginase-1 was more intensely expressed in macrophages in twi mice. Shown is the ventral white matter. Note that Arginase-1 immunoreactivity was also seen in other cell types near the Arginase- $1^{+}$macrophages in twi mice. $\mathbf{D}$, Representative double immunofluorescence staining shows that in twi mice, $\mathrm{CD}_{206}{ }^{+}$cells were mainly localized in the submeningeal spaces (asterisk) and only weakly immunoreactive for Iba-1. 0 ther $\mathrm{CD} 206$ cells were found in the perivascular space (arrowheads). Typical lba- $1^{+}$globoid macrophages did not express CD206 (arrows). E, Quantitation of CD206-expressing macrophages in the spinal white matter (excluding submeningeal space). $\boldsymbol{F}$, Representative double immunofluorescence staining shows that CD16/CD32 was diffusely and weakly expressed in Iba- $1^{+}$microglia in wild-type mice (top) and more intensely expressed in macrophages in twi mice (bottom), although occasional CD16/CD32 ${ }^{+}$, lba- $1^{-}$cells were observed (arrows). Shown is the ventral white matter. G, Quantitation of CD16/CD32-expressing macrophages ( $n=4$ each group). One-way ANOVA followed by Scheffe's Ftest; ${ }^{* *} p<0.01$ and ${ }^{* * * *} p<0.0001$ compared with wild-type mice, and ${ }^{\#} p<0.05$ and ${ }^{\# \# \# \# p} p<0.0001$ compared with $t$ wi mice. The merged images include 4',6-diamidino-2-phenylindole (DAPI) counterstaining in blue. Scale bars, $50 \mu \mathrm{m}$.

\section{Discussion}

Although the genetic basis and biochemical basis of GLD are now largely characterized, the contribution of the accumulated macrophages to its demyelinating pathology has not been determined. In this study, by crossbreeding twi mice with macrophage-deficient $o p$ mice we were able not only to deplete microglia in the CNS of twi mice, but also to block the invasion of macrophages into the CNS. The resultant twi+op doublemutant lived significantly shorter than the twi mouse with more exacerbated neurological symptoms (Fig. 1). Inhibition of remyelination and delay in myelin development, rather than enhanced demyelination, appeared to be responsible for the more severe demyelinating pathology in $t w i+o p$ mice (Fig. 3). 
A
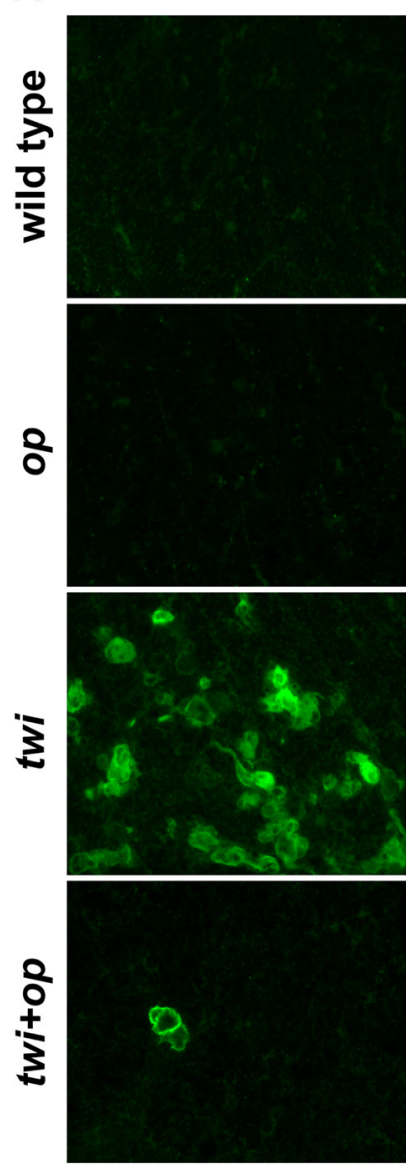

B

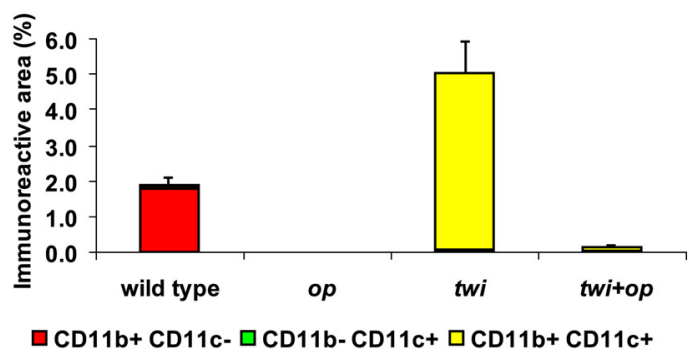

Figure 9. Most macrophages express CD11 c antigen in twi and twi + op mice. A, Double-immunofluorescence staining for CD11c and CD11b in the ventral white matter of the spinal cord at P45.CD11b ${ }^{+}$resting microglia in wild-type mice were mostly $C D 11 c^{-}$, whereas the representative area with densely accumulated macrophages in twi shows that most $\mathrm{CD} 11 \mathrm{~b}^{+}$cells were also $\mathrm{CD} 11 \mathrm{c}^{+}$. There were few macrophages in twi + op mice, but they were mostly positive for CD11c as well. $\boldsymbol{B}$, Morphometric analysis of the CD11c and/or CD11bimmunoreactive areas as shown in $A$. Error bars represent SEM for the sum of $C D 11 \mathrm{~b}^{+/-} \mathrm{CD} 11 \mathrm{C}^{+/-}$areas per group $(n=4)$. The merged images include 4',6-diamidino-2-phenylindole (DAPI) counterstaining in blue. Scale bars, $50 \mu \mathrm{m}$.

It was surprising that the CSF-1 deficiency in twi mice ablated microglia and blocked macrophage infiltration in the CNS white matter (Fig. 2) but did not influence either native macrophage population or migration of macrophages in the peripheral nerves (Fig. $2 B$, arrowheads, Fig. 5). In the myelin protein zero gene-deficient mouse, peripheral motor nerves underwent demyelination with an increased number of macrophages, and when the mouse was crossbred onto the op background, both demyelination and macrophage accumulation were prevented (Carenini et al., 2001; Müller et al., 2007). This contradictory pattern of macrophage behavior in the periphery may indicate that different stimuli recruit different subpopulations of macrophages (e.g., CSF-1 dependency).

It is now widely accepted that macrophages exert multifaceted functions, both beneficial and deleterious, at the site of inflam- mation. In GLD, however, the invasion of blood-borne macrophages into the CNS and the subsequent formation of globoid cells are so massive that conventional wisdom suggested that blocking their migration would benefit the pathology. Our study is the first to provide evidence that macrophages are beneficial as a whole in the pathophysiology of the animal model of GLD by supporting remyelination. Based on previous findings that macrophages in twi mice express high levels of certain key proinflammatory cytokines such as TNF- $\alpha$ and IL- 6 that have been implicated in OL death (LeVine and Brown, 1997), reducing macrophagerelated inflammatory factors has been proposed as a strategy to lessen the demyelinating pathology. However, studies on two knock-out mice [TNF-receptor 1 (Pedchenko et al., 2000) and IL-6 (Pedchenko and LeVine, 1999)] bred onto the twi background demonstrated no change and worsening of demyelination, respectively. These surprising data indicated that proinflammatory cytokines released by macrophages may not necessarily be harmful to myelin maintenance in GLD.

On the contrary, there have been several reports that imply harmful properties of inflammatory molecules in GLD. When the twi mouse was crossed to an MHC II-deficient background, the double mutant showed a less severe "twitching" phenotype with reduced demyelination and a significant decrease in the number of microglia/macrophages in the brain, although its life span was not extended (Matsushima et al., 1994). However, MHC II may not be a major factor that controls the pathophysiology of GLD, because the absence of the MHC II molecule did not improve the pathology in the spinal cord nor alter the life span of twi mice. Indeed, in our study, removal of the upregulated expressions of antigen presentation-related molecules such as CD11c (dendritic cell marker), MHC II, and CD80 and CD86 (costimulatory molecules for antigen presentation) was associated with the worsened pathology in twi+op mice, suggesting that the antigen presentation event is not a major contributing factor in the demyelinating pathology of GLD. Treatment of $t w i$ mice with ibudilast, a phosphodiesterase inhibitor that has been proven to suppress glial cell activation, decreased the number of apoptotic OL and reduced demyelination (Kagitani-Shimono et al., 2005). Mohri et al. (2006) have demonstrated reduced demyelination and some improved clinical signs in twi mice by blocking the pathway between an inflammatory mediator, prostaglandin D2 produced by microglia, and its receptors on astrocytes using gene targeting and pharmacological approaches. These anti-inflammatory approaches have shown some success in improving the pathology in twi mice, but had no effect on extending their life span. 
Recently, treatments with nonsteroidal anti-inflammatory drugs (ibuprofen, minocycline, and indomethacin) prolonged the life span of a transgenic mouse model of GLD by $17-21 \%$ with decreased mRNA levels of proinflammatory cytokines such as IL- 6 and TNF- $\alpha$ (Luzi et al., 2009). These pleiotropic drugs might have exerted not only anti-inflammatory effects but also provided neurons/axons with neuroprotection (Lambat et al., 2000; Sanz-Blasco et al., 2008; Kim and Suh, 2009). Nonetheless the extension of life span is much smaller compared to that following bone marrow transplantation, which can be 2-fold (Yeager et al., 1984) to even over 8-fold in our laboratory (Y.K. and I.D.D., unpublished data).

Levels of IGF-1 and TGF- $\beta_{1}$ mRNA have been reported to increase when macrophages are depleted in a rat model of experimental demyelination (Kotter et al., 2005), whereas increased expression of these molecules in twi mice returned to the level of the wild-type control in twi+op mice in this study. The difference from our study may be that the clodronate-liposome treatment, which Kotter et al. used, effectively blocked migration of bloodborne macrophages into the CNS but did not influence the microglia population. Therefore, resident microglia that responded to the chemical demyelination might have been responsible for the upregulation of IGF- 1 and TGF- $\beta 1$ mRNA.

It may be noteworthy that the levels of IGF- 1 , TGF- $\beta 1$, and LIF mRNA decreased significantly in twi+op mice, even though these molecules are produced by astrocytes that were activated to the same extent as in twi mice as judged by GFAP immunoreactivity and its mRNA expression. This reactive astrocytosis could be a direct effect of psychosine (Giri et al., 2002, 2008), which was elevated in both twi and twi+op mice (Table 2). These results suggest that the morphological changes in astrocytes may not indicate functional alteration of these cells and that expression of IGF-1, TGF- $\beta 1$, and LIF is highly dependent on macrophages.

Other than secreting a series of cytokines and growth factors that are beneficial in the maintenance or repair of myelin, macrophages may facilitate remyelination by phagocytosing myelin debris. Insufficient myelin debris clearance results in inhibition of remyelination (Dubois-Dalcq et al., 2005; Franklin and Kotter, 2008). In chemically induced focally demyelinated lesions in rats, this inhibition seems to result from delayed OPC recruitment when macrophages were depleted by the clodronate-liposome treatment (Kotter et al., 2005) or from an arrest of OPC differentiation into myelinating OLs when myelin debris was exogenously overloaded (Kotter et al., 2006). The difference between the two studies might be that the latter had normal macrophage recruitment in the lesion. Likewise, with a depleted macrophage population this study supports the former mechanism; the upregulation of PDGF-R $\alpha$ mRNA expression in twi mice and the absence of its upregulation in twi+op mice (Fig. 7) indicate that OPC recruitment was compromised even though $\mathrm{NG}^{+}$OPCs appeared to be activated (Fig. 6). In addition to clearing myelin debris that directly inhibits OPC differentiation, macrophages may play an important role in remyelination by regulating the OPC pool.

Together with previous studies on GLD described above, our study suggests that anti-inflammatory approaches either ameliorate or impair the clinical course only to a minor extent. In our study, both M1 and M2 markers on macrophages were increased in the spinal cord of twi mice. In $t w i+o p$ mice, the depletion of macrophages did not appear to change the balance between M1 and M2 and only led to the worsening of demyelinating pathology. The results indicate that simply controlling the number of macrophages may be ineffective as a therapy for GLD. We pro- pose that the functions of macrophages must be modified toward the direction that supports any primary therapies such as hematopoietic stem cell transplantation and replacement of myelinating cells. Such modifications will provide a window of time required before the initiation of the primary therapy, a milieu in which transplanted myelinating cells can survive and remyelinate axons, and/or prevention of the slowly progressive neurodegeneration that occurs in GLD upon transplantation. For example, IL-4, IL-10, and IL-13 can lead macrophages to become a protective M2 phenotype in contrast to the destructive M1 phenotype that can be induced by the proinflammatory cytokine IFN- $\gamma$. The ability to promote macrophages to express an M2 phenotype systemically may be a good future supportive strategy in the treatment of GLD.

\section{References}

Arnett HA, Mason J, Marino M, Suzuki K, Matsushima GK, Ting JP (2001) TNF $\alpha$ promotes proliferation of oligodendrocyte progenitors and remyelination. Nat Neurosci 4:1116-1122.

Arnett HA, Hellendall RP, Matsushima GK, Suzuki K, Laubach VE, Sherman P, Ting JP (2002) The protective role of nitric oxide in a neurotoxicantinduced demyelinating model. J Immunol 168:427-433.

Arnett HA, Wang Y, Matsushima GK, Suzuki K, Ting JP (2003) Functional genomic analysis of remyelination reveals importance of inflammation in oligodendrocyte regeneration. J Neurosci 23:9824-9832.

Austin JH, Lehfeldt D (1965) Studies in globoid (Krabbe) leukodystrophy. III. Significance of experimentally-produced globoid-like elements in rat white matter and spleen. J Neuropathol Exp Neurol 24:265-289.

Biswas S, Biesiada H, Williams TD, LeVine SM (2002) Delayed clinical and pathological signs in twitcher (globoid cell leukodystrophy) mice on a C57BL/6 × CAST/Ei background. Neurobiol Dis 10:344-357.

Bullard DC, Hu X, Adams JE, Schoeb TR, Barnum SR (2007) p150/95 (CD11c/CD18) expression is required for the development of experimental autoimmune encephalomyelitis. Am J Pathol 170:2001-2008.

Cai D, Deng K, Mellado W, Lee J, Ratan RR, Filbin MT (2002) Arginase I and polyamines act downstream from cyclic AMP in overcoming inhibition of axonal growth MAG and myelin in vitro. Neuron 35:711-719.

Carenini S, Mäurer M, Werner A, Blazyca H, Toyka KV, Schmid CD, Raivich G, Martini R (2001) The role of macrophages in demyelinating peripheral nervous system of mice heterozygously deficient in P0. J Cell Biol 152:301-308.

Cerghet M, Skoff RP, Bessert D, Zhang Z, Mullins C, Ghandour MS (2006) Proliferation and death of oligodendrocytes and myelin proteins are differentially regulated in male and female rodents. J Neurosci 26:1439-1447.

Chastain EM, Duncan DS, Rodgers JM, Miller SD (2011) The role of antigen presenting cells in multiple sclerosis. Biochim Biophys Acta 1812:265-274.

Dubois-Dalcq M, Ffrench-Constant C, Franklin RJ (2005) Enhancing central nervous system remyelination in multiple sclerosis. Neuron 48:9-12.

Duchen LW, Eicher EM, Jacobs JM, Scaravilli F, Teixeira F (1980) Hereditary leucodystrophy in the mouse: the new mutant twitcher. Brain 103:695-710.

Franklin RJ, Kotter MR (2008) The biology of CNS remyelination: the key to therapeutic advances. J Neurol 255 [Suppl 1]:19-25.

Futerman AH, Hannun YA (2004) The complex life of simple sphingolipids. EMBO Rep 5:777-782.

Galbiati F, Basso V, Cantuti L, Givogri MI, Lopez-Rosas A, Perez N, Vasu C, Cao H, van Breemen R, Mondino A, Bongarzone ER (2007) Autonomic denervation of lymphoid organs leads to epigenetic immune atrophy in a mouse model of Krabbe disease. J Neurosci 27:13730-13738.

Galea I, Palin K, Newman TA, Van Rooijen N, Perry VH, Boche D (2005) Mannose receptor expression specifically reveals perivascular macrophages in normal, injured, and diseased mouse brain. Glia 49:375-384.

Giri S, Jatana M, Rattan R, Won JS, Singh I, Singh AK (2002) Galactosylsphingosine (psychosine)-induced expression of cytokine-mediated inducible nitric oxide synthases via AP-1 and C/EBP: implications for Krabbe disease. FASEB J 16:661-672.

Giri S, Khan M, Nath N, Singh I, Singh AK (2008) The role of AMPK in 
psychosine mediated effects on oligodendrocytes and astrocytes: implication for Krabbe disease. J Neurochem 105:1820-1833.

Gordon S (2003) Alternative activation of macrophages. Nat Rev Immunol 3:23-35.

Hanisch UK, Kettenmann H (2007) Microglia: active sensor and versatile effector cells in the normal and pathologic brain. Nat Neurosci 10:1387-1394.

Hannun YA, Obeid LM (2008) Principles of bioactive lipid signalling: lessons from sphingolipids. Nat Rev Mol Cell Biol 9:139-150.

Ishibashi T, Dakin KA, Stevens B, Lee PR, Kozlov SV, Stewart CL, Fields RD (2006) Astrocytes promote myelination in response to electrical impulses. Neuron 49:823-832.

Jones LL, Yamaguchi Y, Stallcup WB, Tuszynski MH (2002) NG2 is a major chondroitin sulfate proteoglycan produced after spinal cord injury and is expressed by macrophages and oligodendrocyte progenitors. J Neurosci 22:2792-2803.

Kagitani-Shimono K, Mohri I, Fujitani Y, Suzuki K, Ozono K, Urade Y, Taniike M (2005) Anti-inflammatory therapy by ibudilast, a phosphodiesterase inhibitor, in demyelination of twitcher, a genetic demyelination model. J Neuroinflammation 2:10.

Kigerl KA, Gensel JC, Ankeny DP, Alexander JK, Donnelly DJ, Popovich PG (2009) Identification of two distinct macrophage subsets with divergent effects causing either neurotoxicity or regeneration in the injured mouse spinal cord. J Neurosci 29:13435-13444.

Kim HS, Suh YH (2009) Minocycline and neurodegenerative diseases. Behav Brain Res 196:168-179.

Kim JH, Juraska JM (1997) Sex differences in the development of axon number in the splenium of the rat corpus callosum from postnatal day 15 through 60. Deve Brain Res 102:77-85.

Kondo Y, Duncan ID (2009) Selective reduction in microglia density and function in the white matter of colony-stimulating factor-1-deficient mice. J Neurosci Res 87:2686-2695.

Kondo Y, Wenger DA, Gallo V, Duncan ID (2005) Galactocerebrosidasedeficient oligodendrocytes maintain stable central myelin by exogenous replacement of the missing enzyme in mice. Proc Natl Acad Sci U SA A 102:18670-18675.

Kotter MR, Zhao C, van Rooijen N, Franklin RJ (2005) Macrophagedepletion induced impairment of experimental CNS remyelination is associated with a reduced oligodendrocyte progenitor cell response and altered growth factor expression. Neurobiol Dis 18:166-175.

Kotter MR, Li W-W, Zhao C, Franklin RJM (2006) Myelin impairs CNS remyelination by inhibiting oligodendrocyte precursor cell differentiation. J Neurosci 26:328-332.

Lambat Z, Conrad N, Anoopkumar-Dukie S, Walker RB, Daya S (2000) An investigation into the neuroprotective properties of ibuprofen. Metab Brain Dis 15:249-256.

LeVine SM, Brown DC (1997) IL-6 and TNF $\alpha$ expression in brains of twitcher, quaking and normal mice. J Neuroimmunol 73:47-56.

Li H, Zhang GX, Chen Y, Xu H, Fitzgerald DC, Zhao Z, Rostami A (2008) $\mathrm{CD} 11 \mathrm{c}^{+} \mathrm{CD} 11 \mathrm{~b}^{+}$dendritic cells play an important role in intravenous tolerance and the suppression of experimental autoimmune encephalomyelitis. J Immunol 181:2483-2493.

Li W-W, Penderis J, Zhao C, Schumacher M, Franklin RJM (2006) Females remyelinate more efficiently than males following demyelination in the aged but not young adult CNS. Exp Neurol 202:250-254.

Lieschke GJ, Stanley E, Grail D, Hodgson G, Sinickas V, Gall JA, Sinclair RA, Dunn AR (1994) Mice lacking both macrophage- and granulocytemacrophage colony-stimulating factor have macrophages and coexistent osteopetrosis and severe lung disease. Blood 84:27-35.

Luzi P, Rafi MA, Zaka M, Curtis M, Vanier MT, Wenger DA (2001) Generation of a mouse with low galactocerebrosidase activity by gene targeting: a new model of globoid cell leukodystrophy (Krabbe disease). Mol Genet Metab 73:211-223.

Luzi P, Abraham RM, Rafi MA, Curtis M, Hooper DC, Wenger DA (2009) Effects of treatments on inflammatory and apoptotic markers in the CNS of mice with globoid cell leukodystrophy. Brain Res 1300:146-158.

Mack CM, Boehm GW, Berrebi AS, Denenberg VH (1995) Sex differences in the distribution of axon types within the genu of the rat corpus callosum. Brain Res 697:152-156.

Mantovani A, Sica A, Locati M (2005) Macrophage polarization comes of age. Immunity 23:344-346.

Mason JL, Suzuki K, Chaplin DD, Matsushima GK (2001) Interleukin-1 $\beta$ promotes repair of the CNS. J Neurosci 21:7046-7052.
Matsushima GK, Taniike M, Glimcher LH, Grusby MJ, Frelinger JA, Suzuki K, Ting JP (1994) Absence of MHC class II molecules reduces CNS demyelination, microglial/macrophage infiltration, and twitching in murine globoid cell leukodystrophy. Cell 78:645-656.

Merrill AH Jr (2002) De novo sphingolipid biosynthesis: a necessary, but dangerous, pathway. J Biol Chem 277:25843-25846.

Miyatake T, Suzuki K (1972) Globoid cell leukodystrophy: additional deficiency of psychosine galactosidase. Biochem Biophys Res Commun 48:539-543.

Mohri I, Taniike M, Taniguchi H, Kanekiyo T, Aritake K, Inui T, Fukumoto N, Eguchi N, Kushi A, Sasai H, Kanaoka Y, Ozono K, Narumiya S, Suzuki $\mathrm{K}$, Urade Y (2006) Prostaglandin $\mathrm{D}_{2}$-mediated microglia/astrocyte interaction enhances astrogliosis and demyelination in twitcher. J Neurosci 26:4383-4393.

Müller M, Berghoff M, Kobsar I, Kiefer R, Martini R (2007) Macrophage colony stimulating factor is a crucial factor for the intrinsic macrophage response in mice heterozygously deficient for the myelin protein P0. Exp Neurol 203:55-62.

Neumann H, Kotter MR, Franklin RJM (2008) Debris clearance by microglia: an essential link between degeneration and regeneration. Brain 132:288-295

Ohno M, Komiyama A, Martin PM, Suzuki K (1993) MHC class II antigen expression and T-cell infiltration in the demyelinating CNS and PNS of the twitcher mouse. Brain Res 625:186-196.

Parajuli N, Müller-Holzner E, Böck G, Werner ER, Villunger A, Doppler W (2010) Infiltrating CD11b ${ }^{+} \mathrm{CD} 11 \mathrm{c}^{+}$cells have the potential to mediate inducible nitric oxide synthase-dependent cell death in mammary carcinomas of HER-2/neu transgenic mice. Int J Cancer 126:896-908.

Pedchenko TV, LeVine SM (1999) IL-6 deficiency causes enhanced pathology in Twitcher (globoid cell leukodystrophy) mice. Exp Neurol 158:459-468.

Pedchenko TV, Bronshteyn IG, LeVine SM (2000) TNF-receptor 1 deficiency fails to alter the clinical and pathological course in mice with globoid cell leukodystrophy (twitcher mice) but affords protection following LPS challenge. J Neuroimmunol 110:186-194.

Popovich PG, Longbrake EE (2008) Can the immune system be harnessed to repair the CNS? Nat Rev Neurosci 9:481-493.

Pouly S, Becher B, Blain M, Antel JP (1999) Expression of a homologue of rat NG2 on human microglia. Glia 27:259-268.

Prodinger C, Bunse J, Kruger M, Schiefenhovel F, Brandt C, Laman JD, Greter M, Immig K, Heppner F, Becher B, Bechmann I (2011) CD11cexpressing cells reside in the juxtavascular parenchyma and extend processes into the glia limitans of the mouse nervous system. Acta Neuropathol. Advance online publication. Retrieved November 13, 2010. doi: 10.1007/s00401-010-0774-y.

Rafi MA, Zhi Rao H, Passini MA, Curtis M, Vanier MT, Zaka M, Luzi P, Wolfe JH, Wenger DA (2005) AAV-mediated expression of galactocerebrosidase in brain results in attenuated symptoms and extended life span in murine models of globoid cell leukodystrophy. Mol Ther 11:734-744.

Ramnaraine ML, Clohisy DR (1998) Evaluation of mutant mouse production by mice that are heterogeneous for the $M c f_{s}{ }^{\text {op }}$ gene. Lab Anim Sci 48:300-302.

Rozen S, Skaletsky HJ (2000) Primer3 on the WWW for general users and for biologist programmers. In: Bioinformatics methods and protocols: methods in molecular Biology (Krawetz S, Misener S, eds), pp 365-386. Totowa, NJ: Humana.

Sakai N, Inui K, Tatsumi N, Fukushima H, Nishigaki T, Taniike M, Nishimoto J, Tsukamoto H, Yanagihara I, Ozono K, Okada S (1996) Molecular cloning and expression of cDNA for murine galactocerebrosidase and mutation analysis of the twitcher mouse, a model of Krabbe's disease. J Neurochem 66:1118-1124.

Sanz-Blasco S, Valero RA, Rodríguez-Crespo I, Villalobos C, Núñez L (2008) Mitochondrial $\mathrm{Ca}^{2+}$ overload underlies $\mathrm{A} \beta$ oligomers neurotoxicity providing an unexpected mechanism of neuroprotection by NSAIDs. PLoS One 3:e2718.

Schwartz M, Butovsky O, Brück W, Hanisch U-K (2006) Microglial phenotype: is the commitment reversible? Trends Neurosci 29:68-74.

Suzuki K, Suzuki Y (1970) Globoid cell leucodystrophy (Krabbe's disease): deficiency of galactocerebroside beta-galactosidase. Proc Natl Acad Sci U S A 66:302-309.

Tambuyzer BR, Ponsaerts P, Nouwen EJ (2009) Microglia: gatekeepers of central nervous system immunology. J Leukoc Biol 85:352-370. 
Taniike M, Suzuki K (1994) Spacio-temporal progression of demyelination in twitcher mouse: with clinico-pathological correlation. Acta Neuropathol 88:228-236.

Tansey FA, Cammer W (1991) A pi form of glutathione-S-transferase is a myelin- and oligodendrocyte-associated enzyme in mouse brain. J Neurochem 57:95-102.

Tominaga K, Matsuda J, Kido M, Naito E, Yokota I, Toida K, Ishimura K, Suzuki K, Kuroda Y (2004) Genetic background markedly influences vulnerability of the hippocampal neuronal organization in the "twitcher" mouse model of globoid cell leukodystrophy. J Neurosci Res 77:507-516.

Ulvestad E, Williams K, Bjerkvig R, Tiekotter K, Antel J, Matre R (1994) Human microglial cells have phenotypic and functional characteristics in common with both macrophages and dendritic antigen-presenting cells. J Leukoc Biol 56:732-740.

Wenger DA, Suzuki K, Suzuki Y, Suzuki K (2001) Galactosylceramide lipidosis. Globoid cell leukodystrophy (Krabbe disease). In: The metabolic and molecular bases of inherited disease, 8th Ed (Scriver CR, Beaudet AL, Sly WS, Valle D, Childs B, Kinzler KW, Vogelstein B, eds), pp 3669-3694. New York: McGraw-Hill.

White AB, Givogri MI, Lopez-Rosas A, Cao H, van Breemen R, Thinakaran G, Bongarzone ER (2009) Psychosine accumulates in membrane microdo- mains in the brain of Krabbe patients, disrupting the raft architecture. J Neurosci 29:6068-6077.

Wiktor-Jedrzejczak W, Bartocci A, Ferrante AW Jr, Ahmed-Ansari A, Sell KW, Pollard JW, Stanley ER (1990) Total absence of colony-stimulating factor 1 in the macrophage-deficient osteopetrotic (op/op) mouse. Proc Natl Acad Sci U S A 87:4828-4832.

Witmer-Pack MD, Hughes DA, Schuler G, Lawson L, McWilliam A, Inaba K, Steinman RM, Gordon S (1993) Identification of macrophages and dendritic cells in the osteopetrotic (op/op) mouse. J Cell Sci 104:1021-1029.

Yeager AM, Brennan S, Tiffany C, Moser HW, Santos GW (1984) Prolonged survival and remyelination after hematopoietic cell transplantation in the twitcher mouse. Science 225:1052-1054.

Yoshida H, Hayashi S, Kunisada T, Ogawa M, Nishikawa S, Okamura H, Sudo T, Shultz LD, Nishikawa S (1990) The murine mutation osteopetrosis is in the coding region of the macrophage colony stimulating factor gene. Nature 345:442-444.

Yunis EJ, Lee RE (1969) The ultrastructure of globoid (Krabbe) leukodystrophy. Lab Invest 21:415-419.

Yunis EJ, Lee RE (1970) Tubules of globoid leukodystrophy: a right-handed helix. Science 169:64-66. 